\title{
Diastereoselection in the Formation of Spirocyclic Oxindoles by the Intramolecular Heck Reaction
}

\author{
Larry E. Overman ${ }^{*}$ and Donald A. Watson \\ Department of Chemistry, 516 Rowland Hall, University of California, Irvine, California, 92697-2025
}

\begin{abstract}
Diastereoselective double Heck cyclizations of cyclohexene diamides $\mathbf{1}$ and $\mathbf{3}$ form contiguous quaternary stereocenters, with diastereoselection being controlled by the trans diol-protecting group. In this, the first in a series of two papers, the origin of diastereoselection in the first ring closure step of these reactions is examined. Nine simplified analogues of $\mathbf{1}$ and $\mathbf{3}$ were synthesized and cyclized to discern what structural features are required to realize high diastereoselection in the first intramolecular Heck reaction. These studies show that high stereoselection (>20:1) does not arise from a single structural feature: it is seen only in substrates that contain both a trans acetonide and a tertiary amide substituent at $\mathrm{C} 2$. Two subtle factors appear to be involved: (1) Avoidance of eclipsing interactions between the forming $\mathrm{C}-\mathrm{C}$ bond and the pseudoaxial hydrogen atom at $\mathrm{C} 6$, and between the pseudoequatorial hydrogen atom at $\mathrm{C} 6$ and the carbonyl carbon of the forming spirooxindole; (2) The vinylic amide substituent that is not involved in the insertion event, preferentially adopts a perpendicular conformation placing the sterically bulky $\mathrm{NR}_{2}$ over the alkene $\pi$-bond. Syn-pentanelike interactions between this substituent and $\mathrm{C} 3$ of the cyclohexene are avoided in the favored insertion topography. These two effects, when combined, produce a highly diastereoselective process.
\end{abstract}

\section{Introduction}

Diastereoselective Heck cyclizations that form spirocyclic products without the use of chiral additives are rare. ${ }^{1}$ In the context of total syntheses of meso- and (-)-chimonanthine, this research group described recently the diastereoselective sequential double Heck cyclization of $C_{2}$-symmetric diiodides 1a and 3a to provide spirocyclic dioxindoles 2 and 4 (Scheme 1). ${ }^{2}$ These cyclizations are exceptional in their ability to establish vicinal quaternary carbon stereocenters by a catalytic reaction. ${ }^{3,4}$ Remarkably, the relative configuration of the products was dependent upon the group used to protect the trans diol, a functional group that is remote from the site of the Heck cyclizations. In the case of acetonide-protected diiodide 1a, dioxindole 2 having a trans relationship of its spirooxindole fragments was formed in $90 \%$ yield as a single diastereoisomer. On the other hand, cyclization of trans disiloxy substrate 3a produced preferentially dioxindole 4 (isolated in 64\% yield) having a cis relationship of its spirooxindole units; additional minor products were observed in the unpurified reaction mixture formed upon cyclization of $3 \mathbf{a}^{2}$ Although not disclosed previously, the related ditriflate substrates $\mathbf{1 b}$ and 3b provided nearly identical product mixtures when cyclized under the same conditions. ${ }^{5}$

The cyclization reactions described in Scheme 1 are unique in terms of their diastereoselectivity, the role played by the diol protecting groups, and their ability to construct contiguous quaternary carbon stereocenters. Thus, we sought to better understand these transformations. We chose to pursue this objective by synthesis and subsequent Heck

leoverma@uci.edu. 
cyclization of simplified analogues of $\mathbf{1}$ and $\mathbf{3}$, hoping to discern the structural features required to realize high diastereoselection. In this paper we disclose our investigations of the factors controlling stereoselection in the first cyclization event. These studies show that the origin of diastereoselection in these systems is subtle, resulting from several cooperative factors. In the following paper, we describe related studies directed at understanding the second ring closure event in the sequential double Heck cyclizations of $\mathbf{1}$ and $\mathbf{3}{ }^{6}$

\section{Results}

\section{Diastereoselection in the Cyclization of Disiloxy Substrates 3}

We began our study by more thoroughly defining the product mixture produced upon cyclization of disiloxy substrate 3 . Unlike acetonide $\mathbf{1}$, which cyclizes to provide a single product (as determined by NMR analysis), precursor $\mathbf{3}$ provides a mixture of products upon Heck cyclization. One epimer of dioxindole 4 (isolated in $64 \%$ yield) was the major product reported from cyclization of diiodide $\mathbf{3 a}$; the configuration of the allylic siloxy substituent in this product was not determined at the time of the previous report. ${ }^{2}$ In addition, minor products formed alongside $\mathbf{4}$ were not characterized in our earlier study. ${ }^{2}$ At the time the present study began, aryltriflates had emerged in our laboratories as preferred substrates in Heck cyclization routes to synthesize pyrrolidinoindoline alkaloids. ${ }^{5}$ Therefore, we elected to study in detail the Heck cyclization of disiloxy ditriflate $\mathbf{3 b}$.

Heck cyclization substrates $\mathbf{1 b}$ and $\mathbf{3 b}$ are available in only a few synthetic steps (Scheme 2). Amination of diacyl dichloride 5 with $N$-benzyl-2-(triethylsiloxy)aniline (6) provided the corresponding diamide. Installation of the triflate groups was accomplished in two routine steps to provide 7 in $65 \%$ overall yield. The disubstituted alkene then was converted to the corresponding trans diol by reaction with $m$-chloroperbenzoic acid ( $m$-CPBA), followed by acid hydrolysis of the resultant epoxide. Treatment of this diol with 2,2-dimethoxypropane (2,2-DMP) and catalytic camphorsulfonic acid (CSA) in acetone provided the acetonide ditriflate $1 \mathbf{b}$ in $74 \%$ yield over three steps. Alternatively, protection of the diol by reaction with excess TBDMSOTf in the presence of 2,6-lutidine provided disiloxy ditriflate $\mathbf{3 b}$ in $76 \%$ yield over three steps.

Cyclizations of acetonide ditriflate $\mathbf{1 b}$ and disiloxy ditriflate $\mathbf{3 b}$ were investigated using the reaction conditions summarized in Scheme 1. Similar to diiodide 1a, acetonide-protected ditriflate $\mathbf{1 b}$ underwent double Heck cyclization cleanly to provide trans dioxindole $\mathbf{2}$ in $87 \%$ yield as the single detectable product (by ${ }^{1} \mathrm{H}$ NMR analysis). In contrast, subjection of disiloxy ditriflate $\mathbf{3 b}$ to the same conditions resulted in a more complex mixture of products. Analysis of this mixture by ${ }^{1} \mathrm{H}$ NMR showed that it was similar to that obtained in the cyclization of disiloxy diiodide 3a. ${ }^{7}$ Purification of the crude reaction product by column chromatography provided 4 in $56 \%$ yield, together with shunt reduction product 10 (10\% yield), and a $10 \%$ yield of an equimolar mixture of two additional products $\mathbf{1 1}$ and $\mathbf{1 2}$.

The relative configuration of the major product $\mathbf{4}$ was rigorously defined. After extensive efforts, we found that diffusion of $n$-hexane into a solution of dioxindole 4 in $c a$. 3:1 $\mathrm{Et}_{2} \mathrm{O}-$ EtOAc resulted in crystals suitable for X-ray diffraction analysis. This study, although unable to provide exact metric data because of disorder in the silyl groups, clearly demonstrated the all-cis relationship of the aryl fragments of the spirooxindoles and the allylic siloxy substituent. 8

Structures of the minor products formed upon Heck cyclization of $\mathbf{3 b}$ were determined as follows. The relative configuration of shunt reduction product $\mathbf{1 0}$ was assigned by comparison of its ${ }^{1} \mathrm{H}$ NMR spectrum with those of related compounds of established configuration (see below). Although attempts to separate the two additional products led only to their 
decomposition, the relative configurations of $\mathbf{1 1}$ and $\mathbf{1 2}$ could be assigned by comparison of the ${ }^{1} \mathrm{H}$ NMR spectrum of a mixture of these compounds to ${ }^{1} \mathrm{H}$ NMR spectra of authentic samples of each material. ${ }^{9}$ Each of these products has a trans relationship of its spirooxindole groups. $C_{2}$-symmetric $\mathbf{1 1}$ arises from a cyclization process terminated by reduction, a transformation that is discussed further in the accompanying article.

The ratio of products 4:10:11:12 (65:11:11:13, determined by ${ }^{1} \mathrm{H}$ NMR analysis of the crude cyclization product mixture) generated from Heck cyclization of $\mathbf{3 b}$ suggests that the first spirocyclization in the disiloxy series occurred with moderate diastereoselection, generating an approximate 86:14 mixture of mono-cyclization products $\mathbf{8}$ and $\mathbf{9}$. Intermediate $\mathbf{8}$ then partitions to pentacyclic products $\mathbf{4}$ and $\mathbf{1 1}$ and shunt product 10, whereas intermediate triflate $\mathbf{9}$ cyclizes to provide pentacyclic product $\mathbf{1 2}$.

\section{Synthesis of Model Substrates}

To study the origins of diastereoselection in the first spirocyclization step, a number of monoaryl triflates were synthesized and studied. These model compounds contained various structural features of the $C_{2}$-symmetric substrates $\mathbf{1}$ and $\mathbf{3}$. Cyclization of these model substrates was then undertaken to study the consequence of each substructure on diastereoselection of the first Heck cyclization.

To begin, mono triflates $16 \mathbf{a}$ and $\mathbf{1 6 b}$, in which the cyclohexene double bond is trisubstituted, were prepared. Cyclohexadienoic acid $\mathbf{1 3}^{10}$ was coupled to aniline 6 using 2-chloro-1methylpyridinium iodide (Mukaiyama's salt) ${ }^{11}$ to provide the corresponding anilide (Scheme 4). The triethylsilyl protecting group was removed, and the triflate was installed to provide diene 14. The disubstituted alkene was then converted to trans diol 15,12 which was in turn protected as either an acetonide or a disilyl derivative giving substrate 16a or 16b.

Methyl ester congeners 20a and 20b were prepared in a similar fashion. Low temperature addition of methoxide to anhydride $17^{13}$ provided the corresponding methyl ester (Scheme 5).

14 This mono acid was converted to the corresponding anilide by in situ formation of the acid chloride and subsequent coupling of this intermediate with aniline 6. ${ }^{15,16}$ The resultant aryl silyl ether was then converted directly to triflate 18 in $59 \%$ overall yield from anhydride 17 by treatment with $\mathrm{CsF}$ and $\mathrm{PhNTf}_{2}$. The syntheses of esters $20 \mathrm{a}$ and $\mathbf{2 0 b}$ were completed by installation of the trans ether functionalities, using a sequence similar to the one described previously.

We wished also to study substrates such as $\mathbf{2 3}$ having amide substituents at C2. Initially, we hoped to access these materials from esters $20 \mathbf{a}$ or $\mathbf{2 0 b}$. Unfortunately, all attempts to carry out these transformations failed. For example, as shown in Figure 1, we were unable to hydrolyze ester 21 to give acid 22 using a variety of reagents ( $\mathrm{LiOH}, \mathrm{KOTMS}$, etc.). We believe that cleavage of the ester occurred smoothly, but the resultant carboxylate engaged the $\mathrm{C} 7$ anilide, ejecting $\mathrm{N}$-benzylaniline and providing a pathway for further decomposition.

As earlier studies had shown that metal mediated methods ${ }^{17}$ for the direct conversion of esters to tertiary ortho-alkoxyanilides were not effective in these systems, ${ }^{18}$ an alternative route to the diamide substrates was devised. This sequence, which installed both acylamino groups prior to formation of the cyclohexene ring, is shown in Scheme 6. Lithiation of propiolic acid anilide 24a ${ }^{19}$ followed by quenching with $\mathrm{CO}_{2}$ provided the corresponding acid. Subsequent coupling of this acid with $N$-benzyl-2-(tert-butyldimethylsiloxy)aniline (25) promoted by 1 ethyl-3-(3'-dimethylaminopropyl)carbodiimide hydrochloride (EDCI) resulted in the formation of dianilide $26 \mathbf{a}^{20}$ Attempts to carry out the cycloaddition of 26a and 1,3-butadiene thermally were not successful. At $150^{\circ} \mathrm{C}$ Diels-Alder products were observed, but extensive polymerization of 1,3-butadiene at this temperature made the reaction impractical. After 
screening several Lewis acids, the desired cyclohexadiene was obtained in high yield by the reaction of 26a and 1,3-butadiene at room temperature in the presence of excess $\mathrm{EtAlCl}_{2} \cdot 21$ The cyclohexadiene product was converted easily to triflate 27a. Acetonide 29a and disilyl ether 29b then were obtained by processing triflate $27 \mathbf{a}$ by a standard sequence of steps. Beginning with $N, N$-dimethylpropynamide $(\mathbf{2 4 b})$, the preparation of dimethyl amide 29c proceeded in similar fashion to that of anilides $29 \mathbf{a}$ and $29 \mathbf{b} .^{22}$

Two additional substrates lacking oxidation at C4 and C5 were synthesized also (Scheme 7). tert-Butyl-substituted substrate $\mathbf{3 1}$ was assembled in two steps from the known triflate $\mathbf{3 0}{ }^{23}$ In the first step, the anilide was constructed by palladium-catalyzed carbonylation of $\mathbf{3 0}$ in the presence of aniline 25. ${ }^{24}$ The TBDMS group was then exchanged for triflate by reaction with $\mathrm{CsF}, \mathrm{Cs}_{2} \mathrm{CO}_{3}$ and $\mathrm{PhNTf}_{2}$ to provide 31 in $66 \%$ overall yield. Octalin 33, and its double bond isomer 34, were prepared in $56 \%$ combined yield by a similar two-step sequence from the known mixture of alkene isomers of triflate 32,25 and were separated by preparative HPLC.

\section{Heck Cyclizations}

Intramolecular Heck reactions of model substrates were carried out in identical fashion [20 $\operatorname{mol} \% \mathrm{Pd}\left(\mathrm{PPh}_{3}\right)_{2} \mathrm{Cl}_{2}, 10$ equiv of $\mathrm{Et}_{3} \mathrm{~N}, \mathrm{DMA}, 100{ }^{\circ} \mathrm{C}, 24 \mathrm{~h}$ ], with product ratios being determined by analysis of the ${ }^{1} \mathrm{H}$ NMR spectra of unpurified reaction products. We began by studying the cyclization of acetonide diamide 29a and disiloxy diamide 29b, substrates that contain the dianilide framework of the $C_{2}$-symmetric double Heck precursors $\mathbf{1}$ and $\mathbf{3}$, but lack one triflate functional group. Similar to its $C_{2}$-symmetric counter part, acetonide-protected substrate 29a cyclized to provide spirooxindole 35 as a single detectable isomer (96\% yield). The relative configuration of this product was determined by observation of a $4 \%$ NOE for the aromatic hydrogen atom at $\mathrm{C} 12$ upon irradiation of the methine hydrogen atom at $\mathrm{C} 5 .{ }^{8} \mathrm{On}$ the other hand, cyclization of disiloxy analogue $\mathbf{2 9 b}$ provided a mixture of three products. The two major products, spirooxindoles $\mathbf{1 0}$ and 36, were formed in a 2:1 ratio. These products differ in relative configuration at their spiro stereocenters as determined by comparison of ${ }^{1} \mathrm{H} \mathrm{NMR}$ spectra of these materials with those of the two products produced upon cyclization of disiloxy congener 16b (vide infra), with the signals for the C6 hydrogen atoms being particularly diagnostic. The relative configuration of the enoxysilane 37 was assigned by observation of a series of NOE enhancements, including a $1.7 \%$ enhancement for the $\mathrm{C} 2$ methine hydrogen atom upon irradiation of the pseudoaxial hydrogen atom at $\mathrm{C} 6$ and a $1.8 \%$ enhancement for the $\mathrm{C} 12$ hydrogen atom upon irradiation of the $\mathrm{C} 2$ methine hydrogen atom. ${ }^{8}$ Presumably, enoxysilane $\mathbf{3 7}$ arose from the palladium hydride complex of the major Heck product $\mathbf{1 0}$ by double bond migration. Thus, the overall diastereoselectivity of the Heck cyclization of disiloxy mono triflate $\mathbf{2 9 b}$ was $72: 28$, favoring formation of the spirooxindole isomer having the aryl fragment cis to the C5 siloxy substituent.

Results obtained from cyclizations of aryl triflate substrates $\mathbf{1 6 a}$ and $\mathbf{1 6 b}$, which have no substituent at C2, are summarized in Scheme 9. Cyclization of acetonide precursor 16a gave rise to an 80:20 mixture of epimeric spirooxindoles $\mathbf{3 8}$ and 39. Conversely, cyclization of the disiloxy congener $\mathbf{1 6 b}$ occurred with no stereoselection to give an equal mixture of epimeric spirooxindoles 40 and 41. Relative configurations of products $38-\mathbf{4 1}$ were established by removal of their respective protecting groups to provide the corresponding diols. The relative configuration of the diol derived from disiloxy product $\mathbf{4 1}$ was then determined by X-ray crystallography. 8

Substrates that lacked oxidation at C4 and C5 were studied to see if there was any intrinsic preference for forming an axial $\mathrm{C}-\mathrm{C}$ bond. A small preference of this type was seen with octalin 33, which cyclized to provide a 70:24:6 mixture of spirooxindoles $\mathbf{4 2 ,} \mathbf{4 3}$ and $\mathbf{4 4}$ in $72 \%$ yield (Scheme 10). The relative configurations of the two major products $\mathbf{4 2}$ and $\mathbf{4 3}$, which are epimeric at the $\mathrm{C} 1$ spiro stereocenter, were defined by X-ray crystallographic analysis of $\mathbf{4 2}$. 
8 A series of NOE studies showed that the minor product $\mathbf{4 4}$ had the same relative configuration as 42; diagnostic signals included a $1.7 \%$ enhancement for the $\mathrm{C} 12$ aryl hydrogen atom and a $1.0 \%$ enhancement for the pseudoaxial $\mathrm{C} 6$ hydrogen atom upon irradiation of the pseudoaxial $\mathrm{C} 2$ hydrogen atom.

Little axial preference was seen in the cyclization of the related substrate $\mathbf{3 1}$ in which the cyclohexene ring was anchored with a tert-butyl group. Thus, three spirooxindoles $\mathbf{4 5}, \mathbf{4 6}$ and 47 were formed in a ratio of 50:40:10 and 93\% combined yield. ${ }^{26}$ The relative configurations of epimers $\mathbf{4 5}$ and $\mathbf{4 6}$ were determined by observation of a 2.2\% NOE enhancement for the $\mathrm{C} 12$ aryl hydrogen atom and a 2.4\% NOE enhancement for the hydrogen atom at C4 upon irradiation of the pseudoaxial hydrogen atom at C6 in compound 46. This NOE correlation establishes a trans relationship between the tert-butyl group and the aryl fragment of the spirooxindole in compound 46. Alkene isomer $\mathbf{4 7}$ must arise by double bond isomerization; however, as the initial $\mathrm{C} 4$ stereocenter of substrate $\mathbf{3 1}$ is destroyed in this process, it is not possible to establish how $\mathbf{4 7}$ was formed. ${ }^{27}$

As the presence of an amide substituent at $\mathrm{C} 2$ enhances cyclization diastereoselection in both the acetonide and disiloxy series, we investigated whether or not a simple methyl ester substituent would have a similar effect. Acetonide ester 20a cyclized with low selectivity, providing a 45:21:34 mixture of spirocyclic products $\mathbf{4 8 , 4 9}$ and $\mathbf{5 0}$ in $86 \%$ combined yield (Scheme 11). Again the relative configuration of these products could be assigned by ${ }^{1} \mathrm{H}$ NMR NOE analysis. The major product $\mathbf{4 8}$ displayed a $4.6 \%$ NOE enhancement for the $\mathrm{C} 12$ aryl hydrogen atom when the $\mathrm{C} 5$ methine hydrogen atom was irradiated, indicative of an axial orientation of the aryl portion of the spirooxindole. Conversely, irradiation of the pseudoaxial C6 hydrogen atom of compound 49 resulted in a $4.3 \%$ enhancement for the $\mathrm{C} 4$ hydrogen atom, and importantly, a $1.5 \%$ enhancement for the $\mathrm{C} 12$ aryl hydrogen atom, confirming the pseudoequatorial disposition of the aryl fragment of the oxindole in this epimer. The aryl portion of the oxindole was also pseudoaxial in the enol ether product $\mathbf{5 0}$ as signaled by the observation of a $4.6 \%$ NOE enhancement of the $\mathrm{C} 12$ aryl hydrogen atom upon irradiation of the $\mathrm{C} 5$ hydrogen atom. Irradiation of the $\mathrm{C} 2$ methine hydrogen atom of enol ether $\mathbf{5 0}$ resulted in a 1.4\% NOE of the pseudoaxial C6 hydrogen atom, establishing that methyl ester substituent is pseudoequatorial. Thus in the acetonide series, the overall diastereoselection in forming the spirooxindole was 79:21 favoring the product in which the aryl fragment of the oxindole is pseudoaxial. As observed with other model substrates, disiloxy congener 20b cyclized with lower diastereoselection, providing in this case a 59:41 mixture of spirooxindoles $\mathbf{5 1}$ and $\mathbf{5 2}$ in high yield. Diagnostic signals for the C6 hydrogen atoms (at approximately $2 \mathrm{ppm}$ ) were similar to those seen in the ${ }^{1} \mathrm{H}$ NMR spectra of spirooxindoles $\mathbf{4 0}$ and $\mathbf{4 1}$, thus allowing the relative configuration of products $\mathbf{5 1}$ and $\mathbf{5 2}$ to be specified.

The presence of a methyl ester or $N$-benzylanilide substituent at $\mathrm{C} 2$ had quite different effects on cyclization diastereoselectivity. Thus, we examined Heck cyclization of the $N, N$ dimethylamide congener $29 \mathbf{c}$, which in size would be more similar to the methyl ester (equation 1). Like the dianilide substrates 1b and 29a (Scheme 1 and Scheme 8), amide 29c cyclized with high stereoselectivity to provide a single spirooxindole $\mathbf{5 3}$, isolated in $76 \%$ yield. The observation of a $3.1 \%$ NOE for the $\mathrm{C} 12$ hydrogen atom upon irradiation of the C5 hydrogen atom allowed the relative configuration of $\mathbf{5 3}$ to be specified.

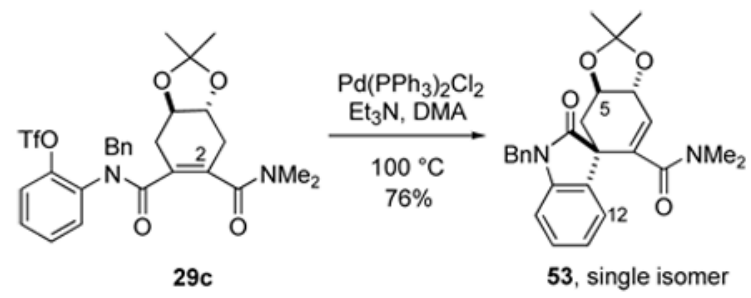

J Org Chem. Author manuscript; available in PMC 2008 November 20. 


\section{Discussion}

Two trends are apparent in the diastereoselective Heck cyclizations examined in the present study. First, substrates containing a trans C4,C5 acetonide undergo Heck cyclization with higher diastereoselectivity (>20-4:1; Scheme 1, Scheme 8, Scheme 9 and Scheme 11, and equation 1) than congeners having the trans C4,C5 diol protected with TBDMS groups (diastereoselectivity = 6-1:1; Scheme 3, Scheme 8, Scheme 11). In the acetonide series, the relative configuration of the spirooxindole in the major product is the same as that of the "firstformed" spirooxindole unit in the cyclization of acetonide ditriflate $\mathbf{1 a} \rightarrow \mathbf{2}$ (Scheme 1): an axial $\mathrm{C}-\mathrm{C}$ bond is formed preferentially upon insertion. When modest stereoselectivity is seen in the disiloxy series, the relative configuration of the newly formed spirooxindole is the opposite: the aryl fragment of the spirooxindole is cis to the C5 siloxy substituent. Second, the presence of a tertiary amide substituent at $\mathrm{C} 2$ significantly enhances diastereoselection in the acetonide-protected substrates compared to substrates lacking this functionality. These two substitution effects are reinforcing; only substrates that contain both a trans C4,C5 acetonide and a C2 tertiary amide substituent $(\mathbf{1}, \mathbf{2 9} \mathbf{a}$ and $\mathbf{2 9}$ c) cyclize with high levels $(>20: 1)$ of diastereoselection.

\section{Diastereoselection in the acetonide series}

Several potential models for interpreting diastereoselection are easily dismissed. First, diastereoselection in the acetonide series does not reflect the thermodynamic stability of the Heck products as the relative configuration of the spirooxindole of the major product places the larger aryl portion of the oxindole axial and the smaller carbonyl group pseudoequatorial. 28 Second, arguments based on the notion that syn insertion would take place preferentially to form the most stable chair conformation of the cyclohexylpalladium intermediate also are not consistent with the observed results. Because of conformational constraints, only two chair intermediates are possible in the acetonide series (Figure 2): in A, which would lead to the observed predominant stereoisomer of the Heck product, the new $\mathrm{C}-\mathrm{C}$ bond is axial, whereas in $\mathbf{B}$, the $\mathrm{C}-\mathrm{Pd}$ bond is axial. As the $\mathrm{R}$ group at $\mathrm{C} 2$ would experience two destabilizing 1,3diaxial interactions in intermediate $\mathbf{A}$, the observation that stereoselection does not decrease as the size of the $\mathrm{C} 2$ substituent $\mathrm{R}$ increases is not consistent with this model. ${ }^{30}$

Consideration of the transition structures for migratory insertion to the alkene faces of the acetonide substrates provides a rationale for the observed diastereoselection (Figure 3). Because of the rigid half-chair conformation of the cyclohexene, the C6 methylene hydrogen atoms are in distinct environments. The same is true for the methylene hydrogen atoms at $\mathrm{C} 3$. In the transition structure leading to the minor products, disfavored transition structure 54a, two major destabilizing interactions result from the C6 hydrogen atoms. First, as migratory insertion occurs to the alkene face proximate to the pseudoaxial $\mathrm{C} 6$ hydrogen atom, formation of the new $\mathrm{C}-\mathrm{C} \sigma$ bond at $\mathrm{C} 1$ results in a developing eclipsed interaction between this new bond and the axial $\mathrm{C} 6-\mathrm{H}$ bond. Second, as migratory insertion occurs, $\mathrm{C} 1$ and $\mathrm{C} 2$ undergo rehybridization from $\mathrm{sp}^{2}$ to $\mathrm{sp}^{3}$. As a result, the alkene substituents move away from the incoming palladium arene. In the disfavored transition structure 54a, this motion results in an eclipsing interaction between the $\mathrm{C} 1-\mathrm{C} 7$ obond and the pseudoequatorial $\mathrm{C} 6-\mathrm{H}$ bond. These destabilizing interactions are illustrated in the modified Newman projection of the disfavored transition structure $\mathbf{5 4 b}$.

On the other hand, in the transition structure leading to the major product (55a, Figure 3), migratory insertion to the alkene face opposite the axial C6 hydrogen atom avoids eclipsing interactions between the $\mathrm{C} 1$ and $\mathrm{C} 6$ substituents (see 55b). Here, the developing eclipsing interactions are predicted to occur between the $\mathrm{C} 2$ and $\mathrm{C} 3$ substituents. One of these interactions involves the developing long $\mathrm{Pd}-\mathrm{C}$ obond and the axial $\mathrm{C} 3-\mathrm{H}$ bond, and the second 
involves the interaction of two $\mathrm{C}-\mathrm{H}$ bonds. Both of these interactions should be less energetically costly than the two $\mathrm{C}-\mathrm{C} / \mathrm{C}-\mathrm{H}$ bond interactions in 54a.

Although the energy differences imparted by these competing eclipsing interactions are not large, only small energy differences between diastereomeric transition structures are required to rationalize stereoselection in Heck cyclizations of substrates lacking amide substituents at $\mathrm{C} 2$.

In order to gain support for our explanation of the observed diastereoselection in the acetonide series in the absence of a C2 substituent, DFT calculations of the two competing transition states for migratory insertion were performed using a slightly simplified model structure. ${ }^{31}$, 32,33,34 As shown in Figure 4, the energies of the calculated transition states $\mathbf{5 6}$ and $\mathbf{5 7}$ predict the formation of the observed diastereomer with a calculated $\Delta \Delta \mathrm{G}^{\ddagger} 373 \mathrm{~K}=1.45 \mathrm{kcal} / \mathrm{mol}$. This free energy difference is roughly consistent with the observed 4:1 ratio of diasteromeric products (corresponding to a $\Delta \Delta \mathrm{G}^{\ddagger} 373 \mathrm{~K}=1.02 \mathrm{kcal} / \mathrm{mol}$ ) in the cyclization of acetonide triflate 16a, which lacks a $\mathrm{C} 2$ substituent. In the higher energy transition state $\mathbf{5 7}$, the calculated dihedral angle between the pseudoequatorial $\mathrm{C} 6-\mathrm{H}$ bond and the $\mathrm{C} 1-\mathrm{C} 7 \sigma$ bond is $6.4^{\circ}$. Likewise, the calculated dihedral angle between the forming $\mathrm{C}-\mathrm{C} \sigma$ bond and the pseudoaxial $\mathrm{C} 6-\mathrm{H}$ bond is $14.3^{\circ}$. These calculations support the hypothesis that avoidance of developing eclipsing interactions in the competing transition states controls face selectivity in the Heck cyclization.

As noted previously, diastereoselection is strongly dependent upon the nature of the $\mathrm{C} 2$ alkene substituent (summarized in Figure 2). The high diastereoselectivity observed in Heck cyclizations of acetonide triflates 29a and 29c demonstrates that the $\mathrm{C} 2$ anilide substituent is critical for realizing high diastereoselectivity in the sequential double Heck cyclization of acetonide ditriflates $\mathbf{1}$. The similar diastereoselectivities observed in Heck cyclizations of methyl ester 20a (Scheme 11) and trisubstituted alkene 16a (Scheme 9) demonstrate that a simple electronic effect is not the origin of the enhanced diastereoselectivity seen with substrates having $\mathrm{C} 2$ amide substituents.

Insight into the role of a $\mathrm{C} 2$ amide substituent is gained by examination of the structures of the Heck cyclization substrates obtained from X-ray crystallographic studies. Figure 5 shows the solid-state structure of methyl ester 20a and dimethyl amide 29c. ${ }^{35}$ Whereas the carbomethoxy of 20a adopts a conformation in which the carbonyl and alkene $\pi$-bonds are coplanar, the acyl group of amide $29 \mathrm{c}$ is nearly perpendicular to the $\pi$-system of the alkene. In both structures, the triflato anilide substituent adopts a similar conformation placing the carbonyl group perpendicular to the alkene. ${ }^{36}$ Molecular mechanics minimizations and dihedral driving experiments show that the favored conformations of the amide substituents results from steric interactions between the $s$-trans R substituent of the amide and the adjacent methylene fragment of the cyclohexene ring (see 59, Figure 6). This interaction destabilizes the conjugated conformation by about $5.5 \mathrm{kcal} / \mathrm{mol}^{8}$ No analogous destabilizing steric interaction is present in the coplanar conformation of the $s$-trans methyl ester (see 58, Figure 6). The favored perpendicular conformation of the amide places the steric bulk of the $\mathrm{NR}_{2}$ fragment either above or below the alkene $\pi$-bond.

Although not shown in Figure 5, X-ray crystallographic studies suggest that the C2 amide substituents could adopt either of the two possible perpendicular conformations with respect to the $\mathrm{C} 1-\mathrm{C} 2$ alkene during the insertion step (Figure 7). ${ }^{35}$ The steric bulk of the $s$-trans nitrogen substituent in these conformations would shield approach to the alkene face that is proximal to the $\mathrm{NR}_{2}$ group. Thus, favored conformations for migratory insertion would be $\mathbf{6 0}$ and $\mathbf{6 1}$ in which the organometallic fragment approaches the alkene from the face of the carbonyl group of the $\mathrm{C} 2$ amide substituent. ${ }^{37}$ 
Further analysis of potential transition structures 60 and 61 provides a reasonable explanation for the role of the $\mathrm{C} 2$ amide substituent in augmenting face diastereoselectivity of the insertion step. As migratory insertion involves the rehybridization of the alkene carbons to $\mathrm{sp}^{3}$, the original alkene substituents would be deflected away from the incoming palladium arene fragments in transition structures 60 and 61 (depicted in more detail in Figure 8). ${ }^{38}$ Of these two possible insertion topographies, $\mathbf{6 1}$ would experience a developing syn-pentane-like steric interaction between the $s$-trans substituent of the amide and the pseudo-axial hydrogen atom at C3. This destabilizing interaction is avoided in the favored diastereomeric transition structure 60. 39,40

Again, in order to further explore the role played by the C2 amide, we undertook a DFT study of the two completing transition states for migratory insertion in a substrate that contained the C2 dimethyl amide. ${ }^{31,32,33}$ Although multiple rotatmers of the $\mathrm{C} 2$ amide were investigated computationally, structures 62 and 63 were the only transition states located (Figure 9). As predicted, the calculated transition states place the bulky $\mathrm{NR}_{2}$ group over the cyclohexene ring in order to avoid steric interactions of this group with the palladium atom and its ligands and the C3 methylene. These calculations largely confirm the model for increased diastereoselection by the $\mathrm{C} 2$ amide advanced above. The lower energy transition state $\mathbf{6 2}$ leads to the observed diastereomer of the cyclization product. The calculated $\Delta \Delta \mathrm{G}^{\ddagger} 373 \mathrm{~K}$ value $(2.16$ $\mathrm{kcal} / \mathrm{mol}$ ) corresponds to higher calculated diastereoselection than in the cases lacking the $\mathrm{C} 2$ amide substituent. As predicted, in the higher energy transition state 63 the $s$-trans methyl group of the dimethyl amide is forced into close proximity $(2.4 \AA)$ to the axial hydrogen atoms at C3. There is also a close contact $(2.5 \AA)$ between this methyl group and the C5 hydrogen atom. Evidently, this interaction with the $\mathrm{C} 3$ hydrogen atom is sufficiently severe to cause rotation of the amide group towards C5. On the other hand, in the lower energy transition state 62, the $s$-trans methyl group of the $\mathrm{C} 2$ amide abuts the hydrogen atom at $\mathrm{C} 4$ with a $\mathrm{H}-\mathrm{H}$ distance of $2.2 \AA$. Although this latter interaction is the closest contact calculated in either pathway, it appears the energetic cost is less severe than the sum of the two interactions in the opposing diastereomeric transition state. When these steric interactions are combined with the eclipsing interactions also present in the transition state (vide infra), a highly diastereoselective transformation results.

\section{Diastereoselection in the disiloxy series}

As expected from the stereoselectivity of the double Heck cyclization of the $C_{2}$-symmetric disiloxy ditriflate $\mathbf{3 b}$, little diastereoselection was observed in the Heck cyclizations of model disiloxy substrates. Of these substrates, disiloxy diamide $\mathbf{2 9 b}$ having the dianilide framework of $\mathbf{3 b}$ but lacking one triflate functional group, cyclized with highest diastereoselectivity provided a 2.6:1 mixture of diastereomeric products. In this case, as in the cyclization of $C_{2}$ symmetric disiloxy ditriflate $\mathbf{3 b}$, the sense of diastereoselection is opposite to that seen in the acetonide series. Because of the low levels of diastereoselection observed in the disiloxy series, $\Delta \Delta \mathrm{G}^{\ddagger}=0.7 \mathrm{kcal} / \mathrm{mol}$ in the case of Heck cyclization of $\mathbf{2 9 b}$, and the fact that these substrates are not conformationally fixed, no convincing rationalization can be provided. 41

\section{Conclusion}

The intramolecular Heck reaction remains among the most powerful reactions available for assembling complex polycyclic organic compounds, particularly those that contain congested all-carbon quaternary stereocenters. This study investigated the origin of stereoselectivity in the first ring-closing event in sequential Heck cyclizations of $C_{2}$-symmetric ditriflates $\mathbf{1 b}$ and 3b that construct complex hexacyclic products containing vicinal all-carbon quaternary stereocenters. The former substrate, in which the trans C3,C4 diol is masked as an acetonide, undergoes a remarkably stereoselective transformation to provide hexacyclic product $\mathbf{2}$ in 
nearly quantitative yield. By examining diastereoselection in Heck cyclizations of simpler congeners in the acetonide series, and by consideration of both computational and crystallographic models, we established that the high diastereoselectivity of the first cyclization step (likely >20:1) derives from two subtle factors: (1) Avoidance of eclipsing interactions between the forming $\mathrm{C}-\mathrm{C}$ bond and the pseudoaxial hydrogen atom at $\mathrm{C} 6$ and between the pseudoequatorial hydrogen atom at C6 and the carbonyl carbon of the forming spirooxindole leads to a moderate preference for insertion from the alkene face proximate to the pseudoequatorial hydrogen atom at C6. (2) The vinylic amide substituent that is not involved in the insertion event, preferentially adopts a perpendicular conformation placing the sterically bulky $\mathrm{NR}_{2}$ over the alkene $\pi$-bond. Syn-pentane-like interactions between this substituent and $\mathrm{C} 3$ of the cyclohexene are avoided in the favored insertion topography. These two effects, when combined, produce a highly diastereoselective process.

In contrast, substrates in which the trans $\mathrm{C} 3, \mathrm{C} 4$ diol is protected with TBDMS groups cyclize with much lower levels of diastereoselection. In the following paper, studies directed at understanding the second ring closure event in sequential double Heck cyclizations of $\mathbf{1}$ and $\mathbf{3}$ are described. 6

\section{Experimental Section 42}

\section{General Procedure for Heck Reactions}

In a glovebox under a nitrogen atmosphere the triflate substrate, $\mathrm{Pd}\left(\mathrm{PPh}_{3}\right)_{2} \mathrm{Cl}_{2}, \mathrm{Et}_{3} \mathrm{~N}$ and DMA were combined in a base-washed, glass vial containing a magnetic stir bar. The vial was sealed with a Teflon-lined cap and placed in a $100{ }^{\circ} \mathrm{C}$ aluminum heating-block (bored to the diameter of the vial) atop a magnetic stir plate. The reaction was maintained with stirring for $24 \mathrm{~h}$ during which time the initial yellow suspension became a deep red, homogenous solution. On occasion, precipitous Pd-black was observed toward the end of the reaction. At the end of the indicated time, the reaction was cooled to room temperature, removed from the glovebox, opened to the atmosphere and diluted with $\mathrm{Et}_{2} \mathrm{O}$. The resultant solution was washed with water twice and once with brine, dried over $\mathrm{MgSO}_{4}$ and concentrated in vacuo. ${ }^{1} \mathrm{H}$ NMR analysis of the crude reaction mixture was then used to determine the diastereomeric ratio of the products formed.

\section{Heck Cyclization of Ditriflate 1b}

According to the general procedure, triflate $1 \mathbf{b}(313 \mathrm{mg}, 360 \mu \mathrm{mol}), \mathrm{Pd}\left(\mathrm{PPh}_{3}\right)_{2} \mathrm{Cl}_{2}(101 \mathrm{mg}$, $144 \mu \mathrm{mol}), \mathrm{Et}_{3} \mathrm{~N}(546 \mathrm{mg}, 0.75 \mathrm{~mL}, 540 \mathrm{mmol})$ and DMA $(4.7 \mathrm{~mL})$ were heated to give dioxindole 2 as a single detectable isomer. Column chromatography (80:20 hexanes-EtOAc) provided $180 \mathrm{mg}(87 \%)$ of dioxindole $\mathbf{2}$ as a colorless solid. Data for $\mathbf{2}$ matched that previously reported. ${ }^{2}$

\section{Heck Cyclization of Ditriflate $3 \mathbf{b}$}

Using a modification of general procedure, triflate $3 \mathbf{b}$ (196 mg, $185 \mu \mathrm{mol}), \mathrm{Pd}_{(}\left(\mathrm{PPh}_{3}\right)_{2} \mathrm{Cl}_{2}(26.9$ $\mathrm{mg}, 37.0 \mu \mathrm{mol}), \mathrm{Et}_{3} \mathrm{~N}(188 \mathrm{mg}, 0.26 \mathrm{~mL}, 1.85 \mathrm{mmol})$ and DMA $(1.9 \mathrm{~mL})$ were heated for 30 $\mathrm{h}$ to give an approximate 65:11:11:13 mixture of 4,10,11 and 12. Due to the complexity of the spectrum, precise integrations of the species present was not possible. Column chromatography (90:10 to 70:30 hexanes- $\mathrm{Et}_{2} \mathrm{O}$ ) allowed for isolation of $78.5 \mathrm{mg}(56 \%)$ of 4 as a colorless oil, $13.3 \mathrm{mg}(10 \%) \mathbf{1 0}$ as an off-white solid and $14.8 \mathrm{mg}(10 \%)$ of an inseparable, approximate equimolar mixture of $\mathbf{1 1}$ and $\mathbf{1 2}$ as a white solid. Pure samples of $\mathbf{1 1}$ and $\mathbf{1 2}$ were independently prepared and characterized, see accompanying article. ${ }^{6}$ Slow diffusion of hexanes into a EtOAc- $\mathrm{Et}_{2} \mathrm{O}$ solution of $\mathbf{4}$ provided crystals suitable for X-ray crystallographic analysis. 
Data for 4: IR (film) 2954, 2929, 2858, 1719, 1652, 1611, $13601250,1171 \mathrm{~cm}^{-1} ;{ }^{1} \mathrm{H}$ NMR $\left(500 \mathrm{MHz}, \mathrm{C}_{6} \mathrm{D}_{6}, \mathrm{rt}\right) \delta 8.43$ (bs, $\left.1 \mathrm{H}\right), 7.29$ (bs, 2H), 7.05 (bs, 2H), 6.82-6.70 (m, 7H), 6.76 (bs, $1 \mathrm{H}), 6.15-6.43(\mathrm{~m}, 5 \mathrm{H}), 4.93-5.10(\mathrm{~m}, 3 \mathrm{H}), 4.64-4.80(\mathrm{~m}, 2 \mathrm{H}), 4.26(\mathrm{bs}, 1 \mathrm{H}), 3.80$ (bd, $J=$ $15.0 \mathrm{~Hz}, 1 \mathrm{H}), 2.01$ (bd, $J=13.0 \mathrm{~Hz}, 1 \mathrm{H}), 1.02(\mathrm{~s}, 9 \mathrm{H}), 0.89$ (s, 9H), 0.15-0.25 (m, 9H), -0.14 (bs, $3 \mathrm{H}) ;{ }^{13} \mathrm{C}$ NMR $\left(125 \mathrm{MHz}, \mathrm{C}_{6} \mathrm{D}_{6}\right.$, rt) $\delta 177.1,176.4,156.5,144.6,143.7,137.2,136.3$, 131.3 , 130.6, 130.1, 129.3, 129.2, 129.1, 129.0, 128.7, 127.7, 127.4, 126.8, 125.9, 122.2, 121.8, 109.7, 109.4, 106.4, 67.1, 55.1, 52.0, 45.0, 43.7, 37.2, 26.6, 26.4, 19.1, 18.5, -3.3, -3.4, -3.9, -4.2; LRMS (ESI) $m / z 757.73(\mathrm{M}+\mathrm{H})^{+}, 779.7(\mathrm{M}+\mathrm{Na})^{+}$; HRMS (ESI) $m / z$ calcd for

$\mathrm{C}_{46} \mathrm{H}_{56} \mathrm{~N}_{2} \mathrm{O}_{4} \mathrm{Si}_{2} 779.3676(\mathrm{M}+\mathrm{Na})^{+}$; found: 779.3684. The ${ }^{1} \mathrm{H}$ NMR spectrum was also recorded in $\mathrm{d}_{8}$-toluene at $100{ }^{\circ} \mathrm{C}$ and $\mathrm{CDCl}_{3}$ at room temperature, see Supporting Information for details.

Data for 10: IR (film) 2930, 2856, 1714, 1629, $1100 \mathrm{~cm}^{-1} ;{ }^{1} \mathrm{H}$ NMR $\left(500 \mathrm{MHz}, \mathrm{C}_{6} \mathrm{D}_{6}\right) \delta 7.37$ $(\mathrm{d}, J=7.5 \mathrm{~Hz}, 2 \mathrm{H}) .7 .13-7.16(\mathrm{~m}, 2 \mathrm{H}), 6.86-7.07(\mathrm{~m}, 10 \mathrm{H}), 6.84-6.80(\mathrm{~m}, 2 \mathrm{H}), 6.70-6.75(\mathrm{~m}$, 2H) $6.57(\mathrm{~d}, J=7.8 \mathrm{~Hz}, 1 \mathrm{H}), 5.88(\mathrm{~d}, J=1.8 \mathrm{~Hz} 1 \mathrm{H}), 5.27(\mathrm{~d}, J=16.0 \mathrm{~Hz}, 1 \mathrm{H}), 5.13(\mathrm{~d}, J=$ $14.8 \mathrm{~Hz}, 1 \mathrm{H}), 5.07$ (ddd, $J=11.4,7.7,3.6 \mathrm{~Hz}, 1 \mathrm{H}), 4.57$ (d, $J=15.7 \mathrm{~Hz}, 1 \mathrm{H}), 4.14$ (d, $J=14.8$ $\mathrm{Hz}, 1 \mathrm{H}), 4.04(\mathrm{dd}, J=7.7,1.7 \mathrm{~Hz}, 1 \mathrm{H}), 2.06(\mathrm{dd}, J=13.7,3.7 \mathrm{~Hz}, 1 \mathrm{H}) 1.94(\mathrm{t}, J=11.8 \mathrm{~Hz}$, $1 \mathrm{H}), 0.96$ (s, 18H), 0.19 (s, 3H), 0.18 (s, 3H), 0.12 (s, 3H), -0.11 (s, 3H); ${ }^{13} \mathrm{C} \mathrm{NMR}(125 \mathrm{MHz}$, $\left.\mathrm{C}_{6} \mathrm{D}_{6}\right) \delta 178.5,167.2,145.1,144.4,143.2,138.3,137.7,133.1,129.8,129.2,129.0,128.9$, $128.8,128.72$, 128.68, 128.1, 127.8, 127.6, 127.5, 123.4, 121.9, 110.0, 74.1, 69.2, 54.4, 53.3, 44.8, 41.2, 26.68, 26.66, 18.7, 18.4, -3.46, -3.49, -4.2 (b); LRMS (ESI) $m / z$. 759.59 (M $+\mathrm{H})^{+}, 781.58(\mathrm{M}+\mathrm{Na})^{+}$; HRMS (ESI) Calcd for $\mathrm{C}_{46} \mathrm{H}_{58} \mathrm{~N}_{2} \mathrm{O}_{4} \mathrm{Si}_{2} \mathrm{~m} / z 781.3833(\mathrm{M}+\mathrm{Na})^{+}$; found: 781.3857 .

\section{Heck Cyclization of Triflate 29a}

According to the general procedure, triflate 29a (104 mg, $184 \mu \mathrm{mol}), \mathrm{Pd}\left(\mathrm{PPh}_{3}\right)_{2} \mathrm{Cl}_{2}(20.3 \mathrm{mg}$, $29.0 \mu \mathrm{mol}), \mathrm{Et}_{3} \mathrm{~N}(146 \mathrm{mg}, 0.20 \mathrm{~mL}, 1.46 \mathrm{mmol})$ and DMA $(1.5 \mathrm{~mL})$ were heated to give spirooxindole 35 as a single detectable isomer. Column chromatography (50:50 hexanes$\mathrm{Et}_{2} \mathrm{O}$ ) provided $79.3 \mathrm{mg}(96 \%$ ) of 35 as a colorless oil: IR (film) 3035, 2985, 1717, 1646, 1613, 1495, $12271073 \mathrm{~cm}^{-1}$; ${ }^{1} \mathrm{H}$ NMR $\left(500 \mathrm{MHz}, \mathrm{C}_{6} \mathrm{D}_{6}\right) \delta 7.39(\mathrm{~d}, J=7.4 \mathrm{~Hz}, 2 \mathrm{H}), 7.10-7.14(\mathrm{~m}$, $5 \mathrm{H}), 6.78-7.04(\mathrm{~m}, 11 \mathrm{H}), 6.56(\mathrm{~d}, J=7.6 \mathrm{~Hz}, 1 \mathrm{H}), 6.22(\mathrm{~d}, J=1.2 \mathrm{~Hz}, 1 \mathrm{H}), 5.03(\mathrm{~d}, J=14.7$ $\mathrm{Hz}, 1 \mathrm{H}), 4.96(\mathrm{~d}, J=16.1 \mathrm{~Hz}, 1 \mathrm{H}), 4.87(\mathrm{~d}, J=16.1 \mathrm{~Hz}, 1 \mathrm{H}), 4.37$ (dd, $J=8.3,1.7 \mathrm{~Hz}, 1 \mathrm{H})$, $4.31(\mathrm{~d}, J=14.7 \mathrm{~Hz}, 1 \mathrm{H}), 3.90(\mathrm{ddd}, J=12.6,8.3,4.1 \mathrm{~Hz}, 1 \mathrm{H}), 2.69(\mathrm{t}, J=12.1 \mathrm{~Hz}, 1 \mathrm{H}), 2.18$ $(\mathrm{dd}, J=11.9,4.1 \mathrm{~Hz}, 1 \mathrm{H}), 1.29(\mathrm{~s}, 3 \mathrm{H}), 1.27(\mathrm{~s}, 3 \mathrm{H}) ;{ }^{13} \mathrm{C} \mathrm{NMR}\left(125 \mathrm{MHz}, \mathrm{C}_{6} \mathrm{D}_{6}\right) \delta 179.0$, $166.8,144.3$, 144.2, 138.2, 137.7, 137.1, 135.4, 133.8, 129.5, 129.2, 128.9, 128.84, 128.81, 128.76, 128.0, 127.8, 127.64, 127.60; 123.6, 122.2, 112.5, 110.2, 78.2, 75.7, 54.8, 54.4, 45.0, 37.9, 27.3, 27.1; LRMS (ESI) $m / z 571.28(\mathrm{M}+\mathrm{H})^{+}, 593.27(\mathrm{M}+\mathrm{Na})^{+}$; HRMS (ESI) Calcd for $\mathrm{C}_{37} \mathrm{H}_{34} \mathrm{~N}_{2} \mathrm{O}_{4} m / z$ 593.2416 (M+Na) ${ }^{+}$; found: 593.2412.

\section{Heck Cyclization of Triflate 29b}

According to the general procedure, triflate $29 \mathbf{b}(280 \mathrm{mg}, 0.308 \mathrm{mmol}), \mathrm{Pd}\left(\mathrm{PPh}_{3}\right)_{2} \mathrm{Cl}_{2}(43.2$ $\mathrm{mg}, 55.6 \mu \mathrm{mol}), \mathrm{Et}_{3} \mathrm{~N}(310 \mathrm{mg}, 0.43 \mathrm{~mL}, 3.08 \mathrm{mmol})$ and DMA $(3.1 \mathrm{~mL})$ were heated to give a 60:28:12 mixture of spirooxindoles 10, $\mathbf{3 6}$ and 37. Column chromatography (90:10 hexanesEtOAc) allowed for partial separation of the isomers giving a combined yield of $470 \mathrm{mg}(73 \%)$ of the mixture of isomers. Preparative HPLC (95:4.5:0.5 hexanes-EtOAc-Et $3 \mathrm{~N}, 30 \mathrm{~mL} / \mathrm{min}$, $300 \times 50 \mathrm{~mm}, 5 \mu \mathrm{m}$ silica gel column) provided analytically pure samples of 10, 36 and $\mathbf{3 7}$ each as colorless oils. Data for $\mathbf{1 0}$ matched that reported above.

Data for 36: IR (film) 2930, 2856, 1710, 1633, $1104 \mathrm{~cm}^{-1} ;{ }^{1} \mathrm{H}$ NMR (500 MHz, $\left.\mathrm{C}_{6} \mathrm{D}_{6}\right) \delta 7.46$ (bs, 1H), 7.34-7.40 (m, 3H), 7.13-7.16 (m, 3H), $7.10(\mathrm{t}, J=7.8 \mathrm{~Hz}, 2 \mathrm{H}), 6.95-7.02(\mathrm{~m}, 5 \mathrm{H})$, 6.87-6.92 (m, 2H), 6.77-6.84 (m, 2H) $6.48(\mathrm{~d}, J=7.7 \mathrm{~Hz}, 1 \mathrm{H}), 5.01(\mathrm{~d}, J=2.5 \mathrm{~Hz} 1 \mathrm{H}), 5.03-$ $5.13(\mathrm{~m}, 2 \mathrm{H}), 4.52-4.61(\mathrm{~m}, 2 \mathrm{H}), 4.46(\mathrm{ddd}, J=11.8,7.4,3.7 \mathrm{~Hz}, 1 \mathrm{H}), 4.18(\mathrm{dd}, J=7.5,2.5$ 
$\mathrm{Hz}, 1 \mathrm{H}), 2.67(\mathrm{t}, J=12.5 \mathrm{~Hz}, 1 \mathrm{H}), 1.95(\mathrm{dd}, J=12.6,3.7 \mathrm{~Hz}, 1 \mathrm{H}), 0.97(\mathrm{~s}, 9 \mathrm{H}), 0.84(\mathrm{~s}, 9 \mathrm{H})$, $0.09(\mathrm{~s}, 6 \mathrm{H}),-0.13(\mathrm{~s}, 3 \mathrm{H}),-0.15(\mathrm{~s}, 3 \mathrm{H}) ;{ }^{13} \mathrm{C} \mathrm{NMR}\left(125 \mathrm{MHz}, \mathrm{C}_{6} \mathrm{D}_{6}\right) \delta 179.4,168.2,145.3$, 143.2, 143.0, 138.2, 136.7, 135.6, 132.6, 129.8, 129.3, 128.9, 128.7, 128.4, 127.8, 127.6 (b), 123.7, 122.5, 110.4, 74.8, 71.0, 54.7, 54.2, 44.2, 42.5, 26.7, 26.4, 18.6, 18.4, -3.4, -3.7, -4.2, -4.3; LRMS (ESI) $\mathrm{m} / z 759.61(\mathrm{M}+\mathrm{H})^{+}, 781.60(\mathrm{M}+\mathrm{Na})^{+}$; HRMS (ESI) Calcd for $\mathrm{C}_{46} \mathrm{H}_{58} \mathrm{~N}_{2} \mathrm{O}_{4} \mathrm{Si}_{2} m / z 759.4014(\mathrm{M}+\mathrm{H})^{+}$; found: 759.3994 .

Data for 37: IR (film) 2930, 2856, 1718, 1664, 1613, 1494, $1085 \mathrm{~cm}^{-1}$; ${ }^{1} \mathrm{H}$ NMR (500 MHz, $\left.\mathrm{C}_{6} \mathrm{D}_{6}\right) \delta 7.38(\mathrm{~d}, J=7.4 \mathrm{~Hz}, 2 \mathrm{H}), 7.09(\mathrm{t}, J=7.5 \mathrm{~Hz}, 2 \mathrm{H}), 6.97-7.03(\mathrm{~m}, 4 \mathrm{H}), 6.85-9.95(\mathrm{~m}$, $4 \mathrm{H}), 6.76-6.84(\mathrm{~m}, 6 \mathrm{H}), 6.50(\mathrm{~d}, J=7.8 \mathrm{~Hz}, 1 \mathrm{H}), 5.24-5.28(\mathrm{~m}, 1 \mathrm{H}), 5.11(\mathrm{~d}, J=2.0 \mathrm{~Hz}, 1 \mathrm{H})$, $4.93(\mathrm{~d}, J=15.9 \mathrm{~Hz}, 1 \mathrm{H}), 4.87(\mathrm{~d}, J=15.9 \mathrm{~Hz}, 1 \mathrm{H}), 4.62(\mathrm{~d}, J=15.9 \mathrm{~Hz}, 1 \mathrm{H}), 4.56(\mathrm{~d}, J=$ $15.9 \mathrm{~Hz}, 1 \mathrm{H}), 4.18(\mathrm{t}, J=2.3 \mathrm{~Hz}, 1 \mathrm{H}), 2.34(\mathrm{dd}, J=13.4,6.7 \mathrm{~Hz}, 1 \mathrm{H}), 2.17(\mathrm{dd}, J=13.5,8.8$ $\mathrm{Hz}, 1 \mathrm{H}), 1.12$ (s, 9H), $0.91(\mathrm{~s}, 9 \mathrm{H}), 0.41(\mathrm{~s}, 3 \mathrm{H}), 0.40(\mathrm{~s}, 3 \mathrm{H}), 0.10(\mathrm{~s}, 3 \mathrm{H}), 0.01(\mathrm{~s}, 3 \mathrm{H}) ;{ }^{13} \mathrm{C}$ NMR (125 MHz, $\left.\mathrm{C}_{6} \mathrm{D}_{6}\right) \delta 178.1,170.8,154.2,144.4,143.1,138.7,137.7,132.7,130.0,129.1$ (b), 129.0 (b), 128.8, 128.7, 127.7, 122.8,121.8, 109.6, 101.6, 68.0, 53.7, 50.2, 48.6, 44.4, 42.3, 26.9, 26.5, 19.3, 26.5, 19.3, 18.7, -3.1, -3.2, -3.7, -4.1; LRMS (ESI) $m / z ~ 759.59(\mathrm{M}+\mathrm{H})^{+}$, $781.58(\mathrm{M}+\mathrm{Na})^{+}$; HRMS (ESI) Calcd for $\mathrm{C}_{46} \mathrm{H}_{58} \mathrm{~N}_{2} \mathrm{O}_{4} \mathrm{Si}_{2} m / z 781.3833(\mathrm{M}+\mathrm{Na})^{+}$; found: 781.3849 .

\section{Heck Cyclization of Triflate 16a}

According to the general procedure, triflate 16a (109 mg, $0.213 \mathrm{mmol}), \mathrm{Pd}\left(\mathrm{PPh}_{3}\right)_{2} \mathrm{Cl}_{2}(29.9$ $\mathrm{mg}, 42.6 \mu \mathrm{mol}), \mathrm{Et}_{3} \mathrm{~N}(0.22 \mathrm{~mL})$ and DMA $(1.5 \mathrm{~mL})$ were heated to give a 80:20 mixture of diastereomers $\mathbf{3 8}$ and 39. Purification by column chromatography ( $90: 10$ hexanes-acetone) afforded $65.0 \mathrm{mg}(84 \%)$ of $\mathbf{3 8}$ and $\mathbf{3 9}$ as an inseparable mixture. Spiroxindoles $\mathbf{3 8}$ and $\mathbf{3 9}$ were characterized as the corresponding diols upon removal of the acetonides, see supporting information for details.

\section{Heck Cyclization of Triflate 16b}

According to the general procedure, triflate $16 \mathbf{b}(1.24 \mathrm{~g}, 1.77 \mathrm{mmol}), \mathrm{Pd}\left(\mathrm{PPh}_{3}\right)_{2} \mathrm{Cl}_{2}(250 \mathrm{mg}$, $0.355 \mathrm{mmol}), \mathrm{Et}_{3} \mathrm{~N}(1.35 \mathrm{~g}, 13.3 \mathrm{mmol}, 1.85 \mathrm{~mL})$ and DMA $(10 \mathrm{~mL})$ were heated to give a 50:50 mixture of diastereomers $\mathbf{4 0}$ and $\mathbf{4 1}$. Column chromatography (90:10 hexanes- $\mathrm{Et}_{2} \mathrm{O}$ ) afforded $940 \mathrm{mg}$ (96\%) of a mixture $\mathbf{4 0}$ and $\mathbf{4 1}$. Further chromatography by MPLC partially separated these diastereomers, yielding $350 \mathrm{mg}$ of $\mathbf{4 0}$ and $400 \mathrm{mg}$ of $\mathbf{4 1}$, which were diastereomerically pure by ${ }^{1} \mathrm{H}$ NMR analysis.

Data for 40: IR (film) 2928, 2856, 1715, 1098, $832 \mathrm{~cm}^{-1} ;{ }^{1} \mathrm{H}$ NMR (500 MHz, $\left.\mathrm{CDCl}_{3}\right) \delta 7.31-$ $7.37(\mathrm{~m}, 5 \mathrm{H}), 7.21-7.24(\mathrm{~m}, 2 \mathrm{H}), 7.08(\mathrm{td}, J=7.8,1.0 \mathrm{~Hz}, 1 \mathrm{H}), 6.80(\mathrm{~d}, J=7.6 \mathrm{~Hz}, 1 \mathrm{H}), 5.94$ $(\mathrm{dd}, J=9.8 .1 .9 \mathrm{~Hz}, 1 \mathrm{H}), 5.29(\mathrm{dt}, J=8.0,1.9 \mathrm{~Hz}, 1 \mathrm{H}), 5.06(\mathrm{~d}, J=15.5 \mathrm{~Hz}, 1 \mathrm{H}), 4.84(\mathrm{~d}, J=$ $15.5 \mathrm{~Hz}, 1 \mathrm{H}), 4.64-4.66(\mathrm{~m}, 1 \mathrm{H}), 4.31(\mathrm{dt}, J=7.2,2.0,1 \mathrm{H}), 2.00-2.08(\mathrm{~m}, 2 \mathrm{H}), 1.02(\mathrm{~s}, 9 \mathrm{H})$, 0.95 (s, 9H), 0.23 (s, 3H), 0.22 (s, 3H), 0.20 (s, 3H), 0.18 (s, 3H); ${ }^{13} \mathrm{C}$ NMR $(125 \mathrm{MHz}$, $\left.\mathrm{CDCl}_{3}\right) \delta 178.1,142.1,136.0,135.6,133.3,128.8,128.3,127.6,127.3,125.5,123.7,122.8$, 108.9, 73.2, 69.8, 51.7, 43.7, 39.4, 26.0 (b), 18.1, 18.0, -4.1 (b), -4.6, -4.8; LRMS (ESI) $\mathrm{m} /$ $z 550.29(\mathrm{M}+\mathrm{H})^{+}, 572.27(\mathrm{M}+\mathrm{Na})^{+}$; HRMS (ESI) Calcd for $\mathrm{C}_{32} \mathrm{H}_{47} \mathrm{NO}_{3} \mathrm{Si}_{2} \mathrm{~m} / z 572.2992(\mathrm{M}$ $+\mathrm{H})^{+}$. Found: 572.2985 .

Data for 41: IR (film) 2928, 2856, 1719, 1610, 1100, $836 \mathrm{~cm}^{-1} ;{ }^{1} \mathrm{H}$ NMR $(500 \mathrm{MHz}$, $\left.\mathrm{CDCl}_{3}\right) \delta$ 7.26-7.36 (m, 6H), 7.21 (td, $\left.J=7.8,1.2 \mathrm{~Hz}, 1 \mathrm{H}\right), 7.18(\mathrm{td}, J=7.6,1.0 \mathrm{~Hz}, 1 \mathrm{H}), 6.78$ $(\mathrm{d}, J=7.8 \mathrm{~Hz}, 1 \mathrm{H}), 5.89(\mathrm{dd}, J=9.9,1.7 \mathrm{~Hz}, 1 \mathrm{H}), 5.25(\mathrm{dt}, J=9.8,1.9 \mathrm{~Hz}, 1 \mathrm{H}), 5.03(\mathrm{~d}, J=$ $15.7 \mathrm{~Hz}, 1 \mathrm{H}), 4.89(\mathrm{~d}, J=15.7 \mathrm{~Hz}, 1 \mathrm{H}), 2.80(\mathrm{dt}, J=7.6,1.9,1 \mathrm{H}), 4.12-4.17(\mathrm{~m}, 1 \mathrm{H}), 2.37(\mathrm{t}$, $J=12.5,1 \mathrm{H}), 1.76-1.82(\mathrm{~m}, 1 \mathrm{H}), 1.00(\mathrm{~s}, 9 \mathrm{H}), 0.88(\mathrm{~s}, 9 \mathrm{H}), 0.21(\mathrm{~s}, 3 \mathrm{H}), 0.19(\mathrm{~s}, 3 \mathrm{H}), 0.12(\mathrm{~s}$, $3 \mathrm{H}),-0.01(\mathrm{~s}, 3 \mathrm{H}) ;{ }^{13} \mathrm{C}$ NMR $\left(125 \mathrm{MHz}, \mathrm{CDCl}_{3}\right) \delta 178.7,141.7,135.8,135.3,133.2,128.8$, $128.3,127.7,127.2,124.8,124.2,122.7,109.3,73.3,71.2,52.6,43.9,39.0,26.0,25.9,18.2$, 
17.9, 18.2, 17.9, -39, -4.0, -4.7 (b); LRMS (ESI) $\mathrm{m} / z 550.29(\mathrm{M}+\mathrm{H})^{+}, 572.28(\mathrm{M}+\mathrm{Na})^{+}$; HRMS (ESI) Calcd for $\mathrm{C}_{32} \mathrm{H}_{47} \mathrm{NO}_{3} \mathrm{Si}_{2} \mathrm{~m} / z 572.2992(\mathrm{M}+\mathrm{H})^{+}$. Found: 572.2998.

\section{Heck Cyclization of Triflate 33}

According to the general procedure, triflate $33(142 \mathrm{mg}, 288 \mu \mathrm{mol}), \mathrm{Pd}\left(\mathrm{PPh}_{3}\right)_{2} \mathrm{Cl}_{2}(40.3 \mathrm{mg}$, $58.1 \mu \mathrm{mol}), \mathrm{Et}_{3} \mathrm{~N}(290 \mathrm{mg}, 0.40 \mathrm{~mL}, 2.87 \mathrm{mmol})$ and DMA $(2.8 \mathrm{~mL})$ were heated to give a 70:24:6 mixture of isomers $\mathbf{4 2 ,} \mathbf{4 3}$ and $\mathbf{4 4}$ for an overall diastereoselection of 70:30. Column chromatography (93:7 hexanes- $\mathrm{Et}_{2} \mathrm{O}$ ) allowed for isolation of $56.1 \mathrm{mg}(57 \%)$ of $\mathbf{4 2}$ as a colorless solid and $15.1 \mathrm{mg}(15 \%)$ of a mixture of $\mathbf{4 3}$ and $\mathbf{4 4}$. Crystallization of a small sample of $\mathbf{4 2}$ from hot $n$-heptane gave crystals suitable for X-ray crystallographic analysis. Preparative HPLC ( $40 \mathrm{~mL} / \mathrm{min}$ 97.5:2.5 hexanes-EtOAc, $300 \times 50 \mathrm{~mm}, 5 \mu \mathrm{m}$ silica gel column) allowed for the separation of $\mathbf{4 3}$ and $\mathbf{4 4}$. By this process, $\mathbf{4 3}$ could be obtained as an analytically pure colorless oil. The alkene isomer $\mathbf{4 4}$ was obtained at $c a$. $90 \%$ purity as colorless oil.

Data for 42: IR (film) 2921, 2852, 1711, 1609, 1486, $1347 \mathrm{~cm}^{-1} ;{ }^{1} \mathrm{H}$ NMR $\left(500 \mathrm{MHz}, \mathrm{C}_{6} \mathrm{D}_{6}\right)$ $\delta 7.29-7.38(\mathrm{~m}, 6 \mathrm{H}), 7.21(\mathrm{td}, J=7.7,1.0 \mathrm{~Hz}, 1 \mathrm{H}), 7.07(\mathrm{t}, J=7.3 \mathrm{~Hz}, 1 \mathrm{H}), 6.78(\mathrm{~d}, J=7.8$ $\mathrm{Hz}, 1 \mathrm{H}), 5.97(\mathrm{dd}, J=9.7,1.1 \mathrm{~Hz}, 1 \mathrm{H}), 5.31(\mathrm{~d}, J=9.7 \mathrm{~Hz}, 1 \mathrm{H}), 5.06(\mathrm{~d}, J=15.7 \mathrm{~Hz}, 1 \mathrm{H})$, $4.92(\mathrm{~d}, J=15.7 \mathrm{~Hz}, 1 \mathrm{H}), 2.13(\mathrm{t}, J=13.3 \mathrm{~Hz}, 1 \mathrm{H}), 2.01(\mathrm{t}, J=10.4 \mathrm{~Hz}, 1 \mathrm{H}), 1.84-1.97(\mathrm{~m}$, 2H), 1.64-1.72 (m, 2H), 1.41-1.53 (m, 2H), 1.18-1.32 (m, 4 H) ; ${ }^{13} \mathrm{C}$ NMR (125 MHz, $\left.\mathrm{C}_{6} \mathrm{D}_{6}\right) \delta 180.3,141.7,136.6,135.9,134.9,128.7,127.8,127.5,127.1,124.2,123.8,122.4$, 109.0, 51.6, 43.7, 41.3, 39.3, 37.5, 32.9, 32.8, 29.7, 26.7, 26.6; LRMS (ESI) $\mathrm{m} / z$ 344.11 (M $+\mathrm{H})^{+}, 366.08(\mathrm{M}+\mathrm{Na})^{+}$; HRMS (ESI) Calcd for $\mathrm{C}_{24} \mathrm{H}_{25} \mathrm{NO} 344.2014(\mathrm{M}+\mathrm{H})^{+}$; found 344.2005 .

Data for 43: IR (film) 2921, 2850, 1710, 1609, 1488, $1345 \mathrm{~cm}^{-1} ;{ }^{1} \mathrm{H}$ NMR (500 MHz, $\mathrm{C}_{6} \mathrm{D}_{6}$ ) $\delta 7.28-7.33(\mathrm{~m}, 4 \mathrm{H}), 7.23-7.27(\mathrm{~m}, 1 \mathrm{H}), 7.13(\mathrm{~m}, 2 \mathrm{H}), 7.00(\mathrm{td}, J=7.6,1.0 \mathrm{~Hz}, 1 \mathrm{H}), 6.71(\mathrm{~d}$, $J=7.3 \mathrm{~Hz}, 1 \mathrm{H}), 5.93(\mathrm{~d}, J=10.6 \mathrm{~Hz}, 1 \mathrm{H}), 5.22(\mathrm{ddd}, J=9.3,2.5,1.5 \mathrm{~Hz}, 1 \mathrm{H}), 4.92(\mathrm{~d}, J=$ $15.6 \mathrm{~Hz}, 1 \mathrm{H}), 4.87(\mathrm{~d}, J=15.6 \mathrm{~Hz}, 1 \mathrm{H}), 2.10-2.24(\mathrm{~m}, 1 \mathrm{H}), 1.64-1.84(\mathrm{~m}, 7 \mathrm{H}), 1.26-1.50$ (3H), 1.02-1.10 (m, $1 \mathrm{H}) ;{ }^{13} \mathrm{C}$ NMR $\left(125 \mathrm{MHz}, \mathrm{C}_{6} \mathrm{D}_{6}\right) \delta 179.4,142.2,137.3,136.1,134.9$, 128.7, 127.8, 127.5, 127.3, 124.4, 123.3, 122.7, 108.8, 50.5, 43.7, 41.8, 39.8, 36.2, 32.9, 32.5, 27.0, 26.4; LRMS (ESI) $m / z 344.11(\mathrm{M}+\mathrm{H})^{+}, 366.10(\mathrm{M}+\mathrm{Na})^{+}$; HRMS (ESI) Calcd for $\mathrm{C}_{24} \mathrm{H}_{25} \mathrm{NO} 366.1834(\mathrm{M}+\mathrm{H})^{+}$; found: 366.1826 .

Data for 44 (ca. 90\% purity): IR (film) 2923, 2854, 1711, 1613, 1490, 1466, 1358, 1169 $\mathrm{cm}^{-1} ;{ }_{1}^{1} \mathrm{H}$ NMR $\left(500 \mathrm{MHz}, \mathrm{CDCl}_{3}\right) \delta 7.23-7.33(\mathrm{~m}, 5 \mathrm{H}), 7.18(\mathrm{~d}, J=6.6 \mathrm{~Hz}, 1 \mathrm{H}), 7.12(\mathrm{td}$, $J=7.7,1.2 \mathrm{~Hz}, 1 \mathrm{H}), 7.00(\mathrm{td}, J=7.5,1.0 \mathrm{~Hz}, 1 \mathrm{H}), 6.70(\mathrm{~d}, J=7.8 \mathrm{~Hz}, 1 \mathrm{H}), 5.43(\mathrm{bs}, 1 \mathrm{H}), 4.90$ (d, $J=15.4 \mathrm{~Hz}, 1 \mathrm{H}), 4.84$ (d, $J=15.4 \mathrm{~Hz}, 1 \mathrm{H}), 2.66$ (bs, $1 \mathrm{H}), 2.49(\mathrm{dq}, J=17.6,2.6 \mathrm{~Hz}, 1 \mathrm{H})$, 2.14-2.39 (m, 3H), 1.68-1.90 (m, 5H), 1.38-1.51 (m, $1 \mathrm{H}), 1.23-1.31(\mathrm{~m}, 1 \mathrm{H}), 1.04-1.14(\mathrm{~m}$, $1 \mathrm{H}) ;{ }^{13} \mathrm{C}$ NMR $\left(125 \mathrm{MHz}, \mathrm{C}_{6} \mathrm{D}_{6}\right) \delta 179.8,142.0,141.1,136.3,135.3,128.8,127.54,127.46$, 127.3, 122.6, 122.3, 114.9, 108.7, 45.6, 43.3, 38.8, 34.8, 34.6, 33.7, 33.1, 27.5, 26.2; LRMS (ESI) $m / z 344.12(\mathrm{M}+\mathrm{H})^{+}, 366.11(\mathrm{M}+\mathrm{Na})^{+}$; HRMS (ESI) Calcd for $\mathrm{C}_{24} \mathrm{H}_{25} \mathrm{NO} 366.1834(\mathrm{M}$ $+\mathrm{H})^{+}$; found: 366.1830 .

\section{Heck Cyclization of Triflate 31}

According to the general procedure, triflate $31(255 \mathrm{mg}, 0.514 \mathrm{mmol}), \mathrm{Pd}\left(\mathrm{PPh}_{3}\right)_{2} \mathrm{Cl}_{2}(72.0 \mathrm{mg}$, $103 \mu \mathrm{mol}), \mathrm{Et}_{3} \mathrm{~N}(521 \mathrm{mg}, 5.15 \mathrm{mmol}, 0.65 \mathrm{~mL})$ and DMA $(5 \mathrm{~mL})$ were heated to give a 50:40:10 mixture of $\mathbf{4 5}, \mathbf{4 6}$ and $\mathbf{4 7}$. Column chromatography (95:5 hexanes- $\mathrm{Et}_{2} \mathrm{O}$ ) afforded 76 $\mathrm{mg}$ (43\%) of $\mathbf{4 5}$ as a colorless foam, $73 \mathrm{mg}$ (41\%) of $\mathbf{4 6}$ as a colorless solid and $15 \mathrm{mg}$ (8\%) of $\mathbf{4 7}$ as a colorless foam (93\% combined yield).

Data for 45: IR (film) 3031, 2958, 1710, 1609, 1364, $1179 \mathrm{~cm}^{-1} ;{ }^{1} \mathrm{H}$ NMR (500 MHz, $\left.\mathrm{CDCl}_{3}\right) \delta 7.20-7.30(\mathrm{~m}, 6 \mathrm{H}), 7.12(\mathrm{td}, J=7.7,1.2 \mathrm{~Hz}, 1 \mathrm{H}), 6.97(\mathrm{td}, J=7.6,0.9 \mathrm{~Hz}, 1 \mathrm{H}), 6.69$ 
(d, $J=7.7 \mathrm{~Hz}, 1 \mathrm{H}), 6.15(\mathrm{~d}, J=10.2 \mathrm{~Hz}, 1 \mathrm{H}), 5.41(\mathrm{ddd}, J=10.1,2.6,1.8 \mathrm{~Hz}, 1 \mathrm{H}), 4.98(\mathrm{~d}$, $J=15.7 \mathrm{~Hz}, 1 \mathrm{H}), 4.83(\mathrm{~d}, J=15.7 \mathrm{~Hz}, 1 \mathrm{H}), 2.21(\mathrm{td}, J=13.5,3.0 \mathrm{~Hz}, 1 \mathrm{H}), 2.13-2.16(\mathrm{~m}, 1 \mathrm{H})$, $1.90-1.94(\mathrm{~m}, 1 \mathrm{H}), 1.68-1.78(\mathrm{~m}, 2 \mathrm{H}), 1.00(\mathrm{~s}, 9 \mathrm{H}) ;{ }^{13} \mathrm{C} \mathrm{NMR}\left(125 \mathrm{MHz}, \mathrm{CDCl}_{3}\right) \delta 180.4$, $141.9,135.9,134.5,133.4,128.7,127.8,127.5,127.1,125.2,124.2,122.3,109.0,50.0,44.8$, 43.7, 32.7, 32.5, 27.3, 20.3; LRMS (CI/NH 3 ) $/ 2 / z 345.1(\mathrm{M})^{+}$; HRMS (CI/NH 3 ) Calcd for $\mathrm{C}_{24} \mathrm{H}_{27} \mathrm{NO} \mathrm{m} / 2$ 345.2093 (M) ${ }^{+}$; found: 345.2099 .

Data for 46: IR (film) 3029, 2960, 1711, 1611, 1345, $1167 \mathrm{~cm}^{-1} ;{ }^{1} \mathrm{H}$ NMR $(500 \mathrm{MHz}$, $\left.\mathrm{CDCl}_{3}\right) \delta$ 7.19-7.28 (m, 5H), 7.09-7.12 (m, 2H), $6.98(\mathrm{t}, J=7.5 \mathrm{~Hz}, 1 \mathrm{H}), 6.67(\mathrm{~d}, J=7.5 \mathrm{~Hz}$, $1 \mathrm{H}), 6,15(\mathrm{dd}, J=10.1,1.1 \mathrm{~Hz}, 1 \mathrm{H}), 5.36(\mathrm{dt}, J=10.1,1.6 \mathrm{~Hz}, 1 \mathrm{H}), 4.93(\mathrm{~d}, J=15.7 \mathrm{~Hz}, 1 \mathrm{H})$, $4.73(\mathrm{~d}, J=15.7 \mathrm{~Hz}, 1 \mathrm{H}), 2.26-2.37(\mathrm{~m}, 1 \mathrm{H}), 2.02-2.06(\mathrm{~m}, 1 \mathrm{H}), 1.95-2.00(\mathrm{~m}, 1 \mathrm{H}), 1.86(\mathrm{td}$, $J=13.3,3.1 \mathrm{~Hz}, 1 \mathrm{H}), 1.74-1.77(\mathrm{~m}, 1 \mathrm{H}), 0.98(\mathrm{~m}, 9 \mathrm{H}) ;{ }^{13} \mathrm{C} \mathrm{NMR}\left(125 \mathrm{MHz}, \mathrm{CDCl}_{3}\right) \delta 179.1$, $142.3,136.1,135.2,134.2,128.7,127.8,127.5,127.2$, 126.0, 123.2, 122.5, 108.8, 48.9, 45.1, 43.6, 33.1, 32.9, 27.3, 19.8; LRMS (CI/NH 3 ) $/ z / z 345.1(\mathrm{M})^{+}$; HRMS $\left(\mathrm{CI} / \mathrm{NH}_{3}\right)$ Calcd for $\mathrm{C}_{24} \mathrm{H}_{27} \mathrm{NO} m / z$ 345.2093 (M) ${ }^{+}$; found: 345.2096.

Data for 47: IR (film) 3054, 2962, 1710, 1613, 1486, $1360 \mathrm{~cm}^{-1} ;{ }^{1} \mathrm{H}$ NMR $(500 \mathrm{MHz}$, $\left.\mathrm{CDCl}_{3}\right) \delta 7.27-7.36(\mathrm{~m}, 5 \mathrm{H}), 7.22(\mathrm{~d}, J=7.4 \mathrm{~Hz}, 1 \mathrm{H}), 7.18(\mathrm{t}, J=7.8 \mathrm{~Hz}, 1 \mathrm{H}), 7.00(\mathrm{~d}, J=7.5$ $\mathrm{Hz}, 1 \mathrm{H}), 6.77(\mathrm{~d}, J=7.8 \mathrm{~Hz}, 1 \mathrm{H}), 5.71(\mathrm{bs}, 1 \mathrm{H}), 5.05(\mathrm{~d}, J=15.7 \mathrm{~Hz}, 1 \mathrm{H}), 4.88(\mathrm{~d}, J=15.7$ $\mathrm{Hz}, 1 \mathrm{H}), 2.80(\mathrm{~d}, J=17.4,1 \mathrm{H}), 2.31-2.48(\mathrm{~m}, 2 \mathrm{H}), 2.08-2.18(\mathrm{~m}, 2 \mathrm{H}), 1.65-1.71(\mathrm{~m}, 1 \mathrm{H})$, 1.19 (s, 9H); ${ }^{13} \mathrm{C} \mathrm{NMR}\left(125 \mathrm{MHz}, \mathrm{CDCl}_{3}\right) \delta 181.2,144.9,141.8,136.1,134.7,128.7,127.48$, 127.45, 127.1 123.9, 122.2, 115.5, 108.9, 45.9, 43.6, 35.5, 32.4, 30.3, 29.1, 20.93; LRMS (CI/ $\left.\mathrm{NH}_{3}\right) \mathrm{m} / z$ 345.1 (M) ${ }^{+}$; HRMS $\left(\mathrm{CI} / \mathrm{NH}_{3}\right)$ Calcd for $\mathrm{C}_{24} \mathrm{H}_{27} \mathrm{NO} \mathrm{m} / z 345.2093(\mathrm{M})^{+}$; found: 345.2098 .

\section{Heck Cyclization of Triflate 20a}

According to the general procedure, triflate 20a (166 mg, $291 \mu \mathrm{mol}), \mathrm{Pd}\left(\mathrm{PPh}_{3}\right)_{2} \mathrm{Cl}_{2}(40.7 \mathrm{mg}$, $58.1 \mu \mathrm{mol}), \mathrm{Et}_{3} \mathrm{~N}(294 \mathrm{mg}, 0.41 \mathrm{~mL}, 2.91 \mathrm{mmol})$ and DMA $(2.9 \mathrm{~mL})$ were heated to give a 45:21:34 mixture of isomers $\mathbf{4 8}, \mathbf{4 9}$ and $\mathbf{5 0}$ for an overall diastereoselection of 79:21. Column chromatography $\left(75: 25\right.$ hexanes- $\left.\mathrm{Et}_{2} \mathrm{O}\right)$ afforded $105 \mathrm{mg}(86 \%)$ of a mixture of the three isomers as a slightly yellow oil. These isomers were further purified by preparative HPLC (40 $\mathrm{mL} / \mathrm{min}, 65: 35$ hexanes-EtOAc, $300 \times 50 \mathrm{~mm}, 5 \mu \mathrm{m}$ silica gel column) to give analytically pure samples of each isomer each as colorless oils.

Data for 48: IR (film) 3035, 2952, 1717, 1611, 1358, 1167, $1071 \mathrm{~cm}^{-1} ;{ }^{1} \mathrm{H}$ NMR $(500 \mathrm{MHz}$, $\left.\mathrm{C}_{6} \mathrm{D}_{6}\right) \delta 7.59(\mathrm{~d}, J=1.6 \mathrm{~Hz}, 1 \mathrm{H}), 7.30-7.31(\mathrm{~m}, 2 \mathrm{H}), 7.09-7.12(\mathrm{~m}, 2 \mathrm{H}), 7.02(\mathrm{t}, J=7.4 \mathrm{~Hz}$, $1 \mathrm{H}), 6.83-6.87(\mathrm{~m}, 2 \mathrm{H}), 6.66(\mathrm{td}, J=7.6,0.9 \mathrm{~Hz}, 1 \mathrm{H}), 6.48(\mathrm{~d}, J=7.8 \mathrm{~Hz}, 1 \mathrm{H}), 4.8(\mathrm{~s}, 2 \mathrm{H})$, $4.33(\mathrm{dd}, J=8.5,1.7 \mathrm{~Hz}, 1 \mathrm{H}), 4.11(\mathrm{ddd}, J=12.5,8.5,3.5 \mathrm{~Hz}, 1 \mathrm{H}), 2.96(\mathrm{~s}, 3 \mathrm{H}), 2.66(\mathrm{t}, J=$ $12.7 \mathrm{~Hz}, 1 \mathrm{H}), 2.11(\mathrm{dd}, J=11.7,3.6 \mathrm{~Hz}), 1.46(\mathrm{~s}, 3 \mathrm{H}), 1.36(\mathrm{~s}, 3 \mathrm{H}) ;{ }^{13} \mathrm{C} \mathrm{NMR}(125 \mathrm{MHz}$, $\left.\mathrm{C}_{6} \mathrm{D}_{6}\right) \delta$ 178.6, 164.6, 143.5, 141.3, 137.1, 135.7. 131.9, 129.3, 128.7, 128.1, 128.0, 122.69, 122.68, 112.6, 109.9, 78.5, 75.0, 54.0, 51.8, 44.7, 38.6, 27.4, 27.1; LRMS (ESI; this compound partially decomposed in $\mathrm{MeCN}, \mathrm{t}_{1 / 2} \sim 5 \mathrm{~min}$, during MS analysis, resulting in a more complex spectrum) $\mathrm{m} / \mathrm{z} 420.14(\mathrm{M}+\mathrm{H})^{+}, 442.11(\mathrm{M}+\mathrm{Na})^{+}$; HRMS (ESI) Calcd for $\mathrm{C}_{25} \mathrm{H}_{25} \mathrm{NO}_{3} 420.1811$ $(\mathrm{M}+\mathrm{H})^{+}$; found: 420.1797 .

Data for 49: IR (film) 3035, 2987, 1713, 1613, 1360, $1067 \mathrm{~cm}^{-1} ;{ }^{1} \mathrm{H}$ NMR (500 MHz, $\left.\mathrm{C}_{6} \mathrm{D}_{6}\right)$ $\delta 7.64(\mathrm{~d}, J=1.8 \mathrm{~Hz}, 1 \mathrm{H}), 7.28-7.30(\mathrm{~m}, 2 \mathrm{H}), 7.06-7.09(\mathrm{~m}, 2 \mathrm{H}), 7.00(\mathrm{t}, J=7.3 \mathrm{~Hz}, 1 \mathrm{H})$, $6.86(\mathrm{td}, J=7.6,1.4, \mathrm{~Hz}, 1 \mathrm{H}), 6.75(\mathrm{td}, J=7.4,0.9 \mathrm{~Hz}, 1 \mathrm{H}), 6.71(\mathrm{dd}, J=7.3,1.2 \mathrm{~Hz}, 1 \mathrm{H})$, $6.48(\mathrm{~d}, J=7.8 \mathrm{~Hz}, 1 \mathrm{H}), 4.76-4.85(\mathrm{~m}, 2 \mathrm{H}), 4.72(\mathrm{~d}, J=15.8 \mathrm{~Hz}, 1 \mathrm{H}), 4.24(\mathrm{dd}, J=8.4,1.6$ $\mathrm{Hz}, 1 \mathrm{H}), 2.96(\mathrm{~s}, 3 \mathrm{H}), 2.52$ (dd, $J=12.6,3.8 \mathrm{~Hz}), 1.97(\mathrm{t}, J=12.6 \mathrm{~Hz}, 1 \mathrm{H}), 1.44(\mathrm{~s}, 3 \mathrm{H}), 1.41$ (s, 3H); ${ }^{13} \mathrm{C}$ NMR $\left(125 \mathrm{MHz}, \mathrm{C}_{6} \mathrm{D}_{6}\right) \delta 78.8,164.9,144.0,141.9,137.2,134.6,128.8,128.7$, 128.2, 127.9, 123.0, 122.8, 112.6, 109.8, 78.7, 74.6, 53.2, 51.8, 44.7, 38.0, 27.5, 27.1; LRMS (ESI; his compound partially decomposed in $\mathrm{MeCN}, \mathrm{t}_{1 / 2} \sim 5$ min, during MS analysis, resulting 
in a more complex spectrum) $m / z 420.14(\mathrm{M}+\mathrm{H})^{+}, 442.12(\mathrm{M}+\mathrm{Na})^{+}$; HRMS (ESI) Calcd for $\mathrm{C}_{25} \mathrm{H}_{25} \mathrm{NO}_{3} 420.1811(\mathrm{M}+\mathrm{H})^{+}$; found: 420.1802 .

Data for 50: IR (film) 3035, 2989, 2939, 1740, 1713, 1611, 1196, $1127 \mathrm{~cm}^{-1} ;{ }^{1} \mathrm{H}$ NMR (500 $\left.\mathrm{MHz}, \mathrm{C}_{6} \mathrm{D}_{6}\right) \delta$ 7.26-7.27 (m, 2H), 7.15-7.17 (m, 1H), 7.05-7.08 (m, 2H), $7.00(\mathrm{t}, J=7.4 \mathrm{~Hz}$, $1 \mathrm{H}), 6.84(\mathrm{td}, J=7.2,1.2 \mathrm{~Hz}, 1 \mathrm{H}), 6.65(\mathrm{td}, J=7.6,1.0 \mathrm{~Hz}, 1 \mathrm{H}), 6.48(\mathrm{~d}, J=7.8 \mathrm{~Hz}, 1 \mathrm{H}), 5.25$ (dd, 3.3, 1.7 Hz, 1H), $4.81(\mathrm{~d}, 15.5 \mathrm{~Hz}, 1 \mathrm{H}), 4.69-4.73(\mathrm{~m}, 1 \mathrm{H}), 4.58(\mathrm{~d}, J=15.5 \mathrm{~Hz}, 1 \mathrm{H}), 4.30$ (t, $J=2.9 \mathrm{~Hz}, 1 \mathrm{H}), 2.4(\mathrm{~s}, 3 \mathrm{H}), 2.47(\mathrm{t}, J=11.4 \mathrm{~Hz}, 1 \mathrm{H}), 1.96(\mathrm{dd}, J=11.6,5.3 \mathrm{~Hz}, 1 \mathrm{H}), 1.41$ (s, 3H), 1.27 (s, 3H); ${ }^{13} \mathrm{C}$ NMR $\left(125 \mathrm{MHz}, \mathrm{C}_{6} \mathrm{D}_{6}\right) \delta 179.0,171.3,152.6,143.6,137.1,131.4$, 129.2, 128.8, 128.7, 128.1, 125.1, 122.4, 112.3, 109.6, 91.2, 71.1, 51.4, 50.4, 47.3, 44.5, 38.0, 27.5, 25.2; LRMS (ESI, Note: This compound was found to decompose while in MeCN solution as required for MS analysis and resulted in a more complex spectrum, $\mathrm{t}_{1 / 2} \sim 5 \mathrm{~min}$ ) $m / z 420.17(\mathrm{M}+\mathrm{H})^{+}, 442.14(\mathrm{M}+\mathrm{Na})^{+}$; HRMS (ESI) Calcd for $\mathrm{C}_{25} \mathrm{H}_{25} \mathrm{NO}_{3} 420.1811(\mathrm{M}$ $+\mathrm{H})^{+}$; found: 420.1805 .

\section{Heck Cyclization of Triflate 20b}

According to the general procedure, triflate $20 \mathbf{b}(211 \mathrm{mg}, 0.278 \mathrm{mmol}), \mathrm{Pd}\left(\mathrm{PPh}_{3}\right)_{2} \mathrm{Cl}_{2}(39.0$ $\mathrm{mg}, 55.6 \mu \mathrm{mol}), \mathrm{Et}_{3} \mathrm{~N}(281 \mathrm{mg}, 0.39 \mathrm{~mL}, 2.78 \mathrm{mmol})$ and DMA $(2.8 \mathrm{~mL})$ were heated to give a 59:41 mixture of diastereomers $\mathbf{5 1}$ and $\mathbf{5 2}$. Column chromatography (90:10 hexanes-- $\mathrm{t}_{2} \mathrm{O}$ ) allowed for partial separation of the isomers giving a combined yield of $149 \mathrm{mg}(88 \%)$ of $\mathbf{5 1}$ as a colorless foam and $\mathbf{5 2}$ as a colorless oil.

Data for 51: IR (film) 2929, 2858, 1717, 1613, 1252, $1100 \mathrm{~cm}^{-1} ;{ }^{1} \mathrm{H}$ NMR $(500 \mathrm{MHz}$, $\left.\mathrm{CDCl}_{3}\right) \delta 7.39(\mathrm{~d}, J=7.5 \mathrm{~Hz}, 2 \mathrm{H}), 7.32(\mathrm{t}, J=7.3 \mathrm{~Hz}, 2 \mathrm{H}), 7.24-7.28(\mathrm{~m}, 1 \mathrm{H}), 7.16(\mathrm{t}, J=7.4$ $\mathrm{Hz}, 1 \mathrm{H}), 7.02-7.03(\mathrm{~m}, 2 \mathrm{H}), 6.96(\mathrm{t}, J=7.5 \mathrm{~Hz}, 1 \mathrm{H}), 6.76(\mathrm{~d}, J=7.8 \mathrm{~Hz}, 1 \mathrm{H}), 5.08(\mathrm{~d}, J=15.6$ $\mathrm{Hz}, 1 \mathrm{H}), 4.81(\mathrm{~d}, J=15.6 \mathrm{~Hz}, 1 \mathrm{H}), 4.50(\mathrm{ddd}, J=11.1,7.3,4.0 \mathrm{~Hz}, 1 \mathrm{H}), 4.33(\mathrm{dd}, J=7.3,1.9$ $\mathrm{Hz}, 1 \mathrm{H}), 3.40$ (s, 3H), 1.90-1.99 (m, 2H), 0.97 (s, 9H), 0.86 (s, 9H), 0.21 (s, 3H), 0.17 (s, 3H), $0.11(\mathrm{~s}, 3 \mathrm{H}), 0.07$ (s, 3H); ${ }^{13} \mathrm{C} \mathrm{NMR}\left(125 \mathrm{MHz}, \mathrm{CDCl}_{3}\right) \delta 178.0,165.2,147.0,142.7,136.3$, 133.4, 129.5, 128.7, 128.1, 127.6, 127.5, 122.5, 122.3, 108.9, 73.2, 68.9, 51.8, 51.3, 44.0, 40.8, 26.0 (b), 19.1, 17.9, -4.1, -4.2, -4.6, -4.8; LRMS (ESI) $\mathrm{m} / z$ 608.14 (M+H) ${ }^{+}, 630.12(\mathrm{M}$ $+\mathrm{Na})^{+}$; HRMS (ESI) Calcd for $\mathrm{C}_{34} \mathrm{H}_{49} \mathrm{NO}_{5} \mathrm{Si}_{2} \mathrm{~m} / z 630.3047(\mathrm{M}+\mathrm{Na})^{+}$; found: 630.3039.

Data for 52: IR (film) 2931, 2858, 1719, 1611, 1254, 1115, $1092 \mathrm{~cm}^{-1}$; ${ }^{1} \mathrm{H}$ NMR $(500 \mathrm{MHz}$, $\left.\mathrm{CDCl}_{3}\right) \delta 7.39(\mathrm{~d}, J=7.2 \mathrm{~Hz}, 2 \mathrm{H}), 7.32(\mathrm{t}, J=7.2 \mathrm{~Hz}, 2 \mathrm{H}), 7.24-7.27(\mathrm{~m}, 1 \mathrm{H}), 7.14-7.18(\mathrm{~m}$, 2H), $7.05(\mathrm{~d}, J=2.0 \mathrm{~Hz}, 1 \mathrm{H}), 6.98(\mathrm{t}, J=7.7 \mathrm{~Hz}, 1 \mathrm{H}), 6.74(\mathrm{~d}, 7.7 \mathrm{~Hz}, 1 \mathrm{H}), 4.97(\mathrm{~m}, 2 \mathrm{H}), 4.32$ (dd, $J=7.2,1.9 \mathrm{~Hz}, 1 \mathrm{H}), 4.09$ (ddd, $J=11.4,7.6,3.5,1 \mathrm{H}), 3.49(\mathrm{~s}, 3 \mathrm{H}), 2.29(\mathrm{t}, J=12.7,1 \mathrm{H})$, $1.65(\mathrm{dd}, 13.0,3.6 \mathrm{~Hz}, 1 \mathrm{H}), 0.99$ (s, 9H), 0.80 (s, 9H), 0.21 (s, 3H), 0.17 (s, 3H), 0.03 (s, 3H), -0.16 (s, 3H): ${ }^{13} \mathrm{C} \mathrm{NMR}\left(125 \mathrm{MHz}, \mathrm{CDCl}_{3}\right) \delta 178.7,164.5,147.0,142.3,136.0,133.2,128.7$, 128.2, 127.5, 127.4, 122.8, 122.1, 109.5, 73.6, 70.1, 52.1, 52.0, 44.1, 41.4, 26.0, 25.8, 18.2, $17.9,-4.0,-4.1,-4.7,-4.9$; LRMS (ESI) $\mathrm{m} / z 608.11(\mathrm{M}+\mathrm{H})^{+}, 630.10(\mathrm{M}+\mathrm{Na})^{+}$; HRMS (ESI) Calcd for $\mathrm{C}_{34} \mathrm{H}_{49} \mathrm{NO}_{5} \mathrm{Si}_{2} \mathrm{~m} / z 630.3047(\mathrm{M}+\mathrm{Na})^{+}$; found: 630.3057 .

\section{Heck Cyclization of Triflate 29c}

According to the general procedure, triflate 29c (108 mg, $184 \mu \mathrm{mol}), \mathrm{Pd}\left(\mathrm{PPh}_{3}\right)_{2} \mathrm{Cl}_{2}(25.9 \mathrm{mg}$, $36.9 \mu \mathrm{mol}), \mathrm{Et}_{3} \mathrm{~N}(187 \mathrm{mg}, 0.24 \mathrm{~mL}, 1.85 \mathrm{mmol})$ and DMA $(1.8 \mathrm{~mL})$ were heated to give oxindole $\mathbf{5 3}$ as a single detectable isomer. Column chromatography (50:50 to 30:70 hexanesEtOAc) provided $59.6 \mathrm{mg}$ (76\%) of $\mathbf{5 3}$ as a colorless oil: IR (film) 2827, 2856, 1717, 1644, $1611,1355,1160 \mathrm{~cm}^{-1} ;{ }^{1} \mathrm{H}$ NMR $\left(500 \mathrm{MHz}, \mathrm{C}_{6} \mathrm{D}_{6}\right) \delta 7.30(\mathrm{~d}, J=7.4 \mathrm{~Hz}, 2 \mathrm{H}), 7.10$ (t, $J=7.5$ $\mathrm{Hz}, 2 \mathrm{H}), 6.96-7.03(\mathrm{~m}, 2 \mathrm{H}), 6.72(\mathrm{t}, J=6.7 \mathrm{~Hz}, 1 \mathrm{H}), 6.40(\mathrm{~d}, J=7.8 \mathrm{~Hz}, 1 \mathrm{H}), 6.23(\mathrm{~d}, J=1.5$ $\mathrm{Hz}, 1 \mathrm{H}), 4.79(\mathrm{~m}, 2 \mathrm{H}), 4.56(\mathrm{dd}, J=8.2,1.5 \mathrm{~Hz}, 1 \mathrm{H}), 4.15$ (ddd, $J=12.7,8.2,4.3 \mathrm{~Hz}, 1 \mathrm{H})$, $2.77(\mathrm{t}, J=12.3 \mathrm{~Hz}, 1 \mathrm{H}), 2.32(\mathrm{bs}, 2 \mathrm{H}), 2.23(\mathrm{dd}, J=12.0,4.3,1 \mathrm{H}), 1.54(\mathrm{~s}, 3 \mathrm{H}), 1.42$ (s, $3 \mathrm{H}) ;{ }^{13} \mathrm{C}$ NMR (125 MHz, $\left.\mathrm{C}_{6} \mathrm{D}_{6}\right) \delta 178.2,167.6,143.9,137.1,134.7,134.6,131.5 .129 .2$.

J Org Chem. Author manuscript; available in PMC 2008 November 20. 
$128.9,128.7,128.0,127.8,123.3,122.4,112.7,110.0,77.9,76.9,54.4,44.9,37.7,27.6,27.2$; LRMS (ESI) $m / z 433.45(\mathrm{M}+\mathrm{H})^{+}, 455.43(\mathrm{M}+\mathrm{Na})^{+}$; HRMS (ESI) Calcd for $\mathrm{C}_{26} \mathrm{H}_{28} \mathrm{~N}_{2} \mathrm{O}_{4} \mathrm{~m} /$ z $433.2127(\mathrm{M}+\mathrm{Na})^{+}$; found: 433.2130 .

\section{Supplementary Material}

Refer to Web version on PubMed Central for supplementary material.

\section{Acknowledgements}

This research was supported by the NIH National Institutes of General Medical Sciences (GM-30859) and by predoctoral fellowships from Pharmacia Co. and the UC Regents for D.A.W. Dr. Rob Hinkle and Dr. Brian Stearns are thanked for the development of the synthesis of $\mathbf{1 b}$ and $\mathbf{3 b}$. NMR and mass spectra were determined at UC Irvine using instruments acquired with the assistance of NSF and NIH shared instrumentation grants. DFT calculations were preformed by D.A.W. at the UC Berkeley Molecular Graphics Facility.

\section{References}

1. (a) Dounay AB, Overman LE. Chem. Rev 2003;103:2945-2964. [PubMed: 12914487]Link, JT. The Intramolecular Heck Reaction. In: Overman, LE., editor. Organic Reactions. Vol. 60. New York: John Wiley and Sons; 2002. p. 157-534.Overman, LE.; Link, JT. Intramolecular Heck Reactions in Natural Products Chemistry. In: Stang, PJ.; Diederich, F., editors. Metal Catalyzed Cross-Coupling Reactions. New York: Wiley-VCH; 1998. de Meijere, A.; Brase, S. Palladium-Catalyzed Coupling of Organyl Halides to Alkenes - The Heck Reaction. In: Stang, PJ.; Diederich, F., editors. Metal Catalyzed CrossCoupling Reactions. New York: Wiley-VCH; 1998. (e) de Meijere A, Meyer FE. Angew. Chem. Int. Ed. Engl 1994;33:2379-2411.

2. Overman LE, Paone DV, Stearns BA. J. Am. Chem. Soc 1999;121:7702-7003.

3. There are limited methods known for the construction of contiguous all-carbon quaternary centers. To our knowledge, the examples described from our laboratories are the only catalytic reactions reported for the synthesis of vicinal quaternary carbon stereocenters. See: Peterson EA, Overman LE. Proc. Natl. Acad. Sci. U. S. A 2004;101:11943-11948. [PubMed: 15232003]

4. For general methods for the construction of quaternary carbon stereocenters see: (a) Douglas CJ, Overman LE. Proc. Natl. Acad. Sci. U. S. A 2004;101:5363-5367. [PubMed: 14724294] (b) Denissova I, Barriault L. Tetrahedron 2003;59:10105-10146. (c) Christoffers J, Baro A. Angew. Chem., Int. Ed 2003;42:1688-1690. (d) Christoffers J, Mann A. Angew. Chem. Int. Ed 2001;40:4591-4597. (e) Corey EJ, Guzman-Perez A. Angew. Chem. Int. Ed 1998;37:388-401.

5. Stearns, BA. Ph. D. Thesis. Irvine, CA: University of California, Irvine; 2000. A Formal Synthesis of Loracarbef and Total Synthesis of Polypyrrolidinoindoline Alkaloids.

6. Overman LE, Watson DA. following contribution in this issue.

7. To allow complete conversion of intermediates produced from the ditriflate precursor to the observed final products 4 and 10-12, longer reaction times were required than in cyclizations of the corresponding diiodide.

8. See Supporting Information for additional details.

9. See the accompanying article for preparation and characterization of $\mathbf{1 1}$ and $\mathbf{1 2} .^{6}$

10. Emerman SL, Meinwald J. J. Org. Chem 1956;21:375.

11. Bald E, Saigo K, Mukaiyama T. Chem. Lett 1975:1163-1166.

12. A minor byproduct from competitive oxidation of the cyclohexadiene to the corresponding arene was observed also in the epoxidation step. This material proved difficult to separate from the desired product prior to conversion to diol $\mathbf{1 5 .}$

13. Maier G, Sayrac T, Reisenauer HP. Chem. Ber 1982;115:2202-2213.

14. Attempts to use other nucleophiles in this reaction, in particular anilines or their metal salts, led to complex mixtures of products.

15. Other activation strategies, such as use of Mukaiyama's salt, provided the coupled product in low yield only. Increased steric crowding imparted by the proximity of the $\mathrm{C} 2$ ester likely makes amide formation more challenging in this series. 
16. The choice of ethyl ether as the solvent proved critical in this sequence; the use of methylene chloride as solvent yielded only trace amounts of product.

17. (a) Basha A, Lipton M, Weinreb SM. Tetrahedron Lett 1977;48:4171-4174. (b) Willimas JM, Jobson RB, Yasuda N, Marchesini G, Dolling UH, Grabowski EJJ. Tetrahedron Lett 1995;36:5461-5464.

18. Watson, DA. Ph. D. Thesis. Irvine, CA: University of California, Irvine; 2004. Investigation into the Origins of Diastereoselection in Spirocyclic Oxindole Forming Intramolecular Heck Cyclizations.

19. Alkyne 24a is available in one step from propiolic acid and $N$-benzylaniline.

20. Several reagents were examined as promoters for this coupling, but only carbodiimide reagents were successful.

21. (a) Milder Lewis acids such as $\mathrm{Me}_{2} \mathrm{AlCl}$ did not promote the reaction at room temperature. (b) Substoichiometric quantities of 2,6-di-tert-butyl-4-methylpyridine (DTBMP) were added to prevent Brönsted acid-promoted side reactions such as alkene migration.

22. Crow WD, Leonard NJ. J. Org. Chem 1965;30:2660-2665.

23. McMurry JE, Scott WJ. Tetrahedron Lett 1983;24:979-982.

24. Cacchi S, Ciattini PG, Morera E, Ortar G. Tetrahedron Lett 1986;37:3931-3934.

25. Collins CJ, Martinez AG, Alvarez RM, Aguirre JA. Chem. Ber 1984;117:2815-2824.

26. This ratio matches the ratio previously observed in a similar reaction. See: Abelman MM, Oh T, Overman LE. J. Org. Chem 1987;52:4130-4133.

27. Resubjection of the isolated products to the cyclization conditions resulted in no further alkene migration.

28. For example, molecular mechanics calculations indicate that $\mathbf{3 8}$ is $0.76 \mathrm{kcal} / \mathrm{mol}$ less stable than its spirooxindole epimer 39; Monte Carlo conformation searches performed using the Macromodel 8.0 implementation of the MM2* force field and the Maestro 5.0 interface. ${ }^{29}$

29. Schrödinger LLC, Portland OR. 2003

30. Models based upon the notion that increases or decreases in torsional strain of the fused trans acetonide in different insertion topographies could be important also does not rationalize the observed results. 18

31. Transition state optimizations were preformed using B3LYP/LACVP**+ level of theory as implemented in Jaguar 5.5..$^{29}$ Transition states were characterized by a single imagery frequency. The energies reported were calculated at $373 \mathrm{~K}$, corresponding to the experimental reaction temperature for the Heck cyclizations.

32. For computational ease, a methylidene acetyl was used in place of the acetonide, the benzyl group was replaced with hydrogen atom and phosphine replaced triphenylphosphine.

33. We assume that the neutral trans $\mathrm{Ar} / \mathrm{Cl}$ palladium fragment is the catalytically active species in solution based upon the demonstrated importance of anionic ligands in solution in palladium catalyzed processes. ${ }^{34}$ The calculated transition state energies shown in the text are specific for the trans $\mathrm{Ar} / \mathrm{Cl}$ palladium fragment, as shown. Other possibilities were also considered. The two transition states for the cis $\mathrm{Ar} / \mathrm{Cl}$ palladium isomer were also calculated but found higher in energy. The cationic $\mathrm{LPd}\left(\mathrm{PH}_{3}\right)_{2}{ }^{+}$transition states were also calculated. The energies of these cationic isomers are difficult to compare to the neutral species. However, in all cases the calculated $\Delta \Delta \mathrm{G}^{\dagger}{ }_{373}$ favored the transition state leading to the observed diastereomer by approximately the same energtic difference. Details of these additional calculations can be found in the Supporting Information.

34. Amatore C, Jutand A. Acc. Chem. Res 2000;33:314-321. [PubMed: 10813876] and references therein.

35. For both methyl ester 20a and dimethyl amide 29c, X-ray crystallographic studies revealed two conformations in the solid-state that differ in the orientation of the triflato anilide substituent about the $\mathrm{C} 2-\mathrm{C} 7$ bond (Figure 4). In both conformations, the amides adopt non-conjugated conformations. For clarity, Figure 8 shows only one of these conformations. Complete depictions of the unit cells of the compounds can be found in the Supporting Information.

36. X-ray crystallographic studies were also performed on ditriflate $\mathbf{1 b}$ and dianilide 29a. The results from these studies show similar amide conformations to that of $29 \mathbf{c}$ and are presented in the Supporting Information.

37. Mechanical and computational models, ${ }^{18}$ as well as crystallographic data, show that the two possible conformations of the $\mathrm{C} 2$ amides have similar energies. Therefore, diastereoselection in Heck 
cyclizations of these substrates does not derive from ground state conformational preferences of the amide.

38. This analysis assumes a relatively early transition state for the migratory insertion. As previously argued, the trend of increased diastereoselection with large $\mathrm{C} 2$ amides precludes a late-transition state as the developing 1,3-diaxial interaction between the amide and the $\mathrm{C} 4$ hydrogen atom would result in lowered diastereoselection.

39. The developing C-Pd bond in $\mathbf{5 8}$ and $\mathbf{5 9}$ is long and therefore the potential steric interactions between it and the adjacent hydrogen atoms are expected to be of minimal consequence.

40. Similar gearing effects have been previously noted in other systems, see, inter alia: (a) Roush WR, Lane GC. Org. Lett 1999;1:95-98. [PubMed: 10822542] (b) Walsh PJ, Lurain AE, Balsells J. Chem. Rev 2003;103:3297-3344. [PubMed: 12914499]

41. Previously, it was postulated that the ability of the siloxy groups to adopt a trans-diaxial orientation, and thus the cyclohexene ring the opposite half-chair conformation as that enforced in the acetonide series might be important in influencing diasteroselection in the Heck cyclizations of $3 \mathbf{a}^{2}$ More than this factor must be involved as disiloxy triflate 16b, which lacks a C2 substituent, cyclized with no stereoselectivity.

42. General experimental details have been described: MacMillan DWC, Overman LE, Pennington LD. J. Am. Chem. Soc 2001;123:9033-9044. [PubMed: 11552811](b) CCDC 288970-288975 contains the supplementary crystallographic data for this paper. These data can be obtained free of charge from The Cambridge Crystallographic Data Centre via www.ccdc.cam.ac.uk/data_request/cif. 


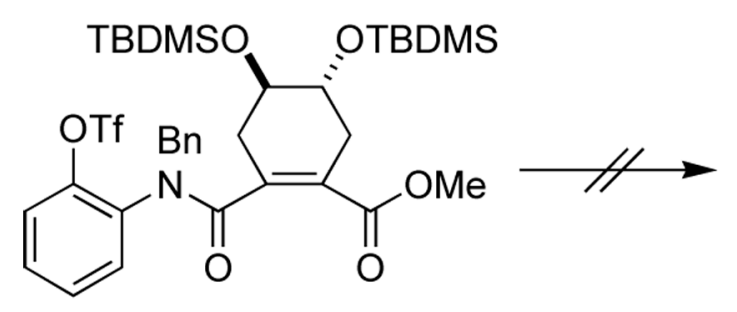

21

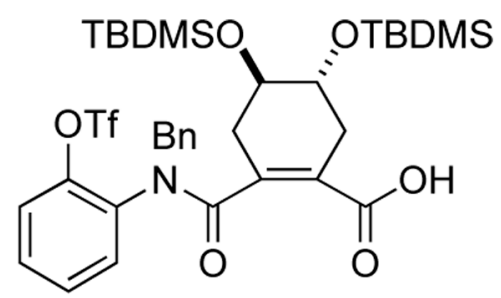

22

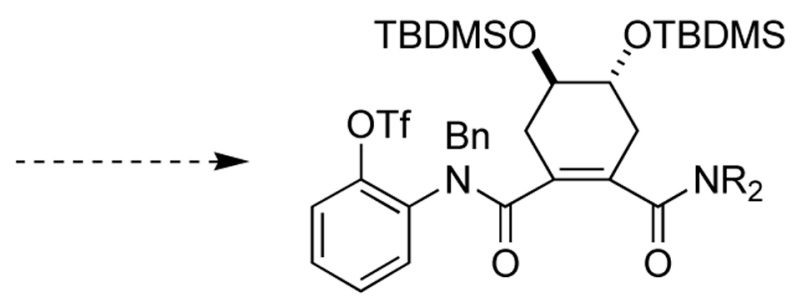

23

FIGURE 1.

Failed strategy for preparing diamide $\mathbf{2 3}$. 


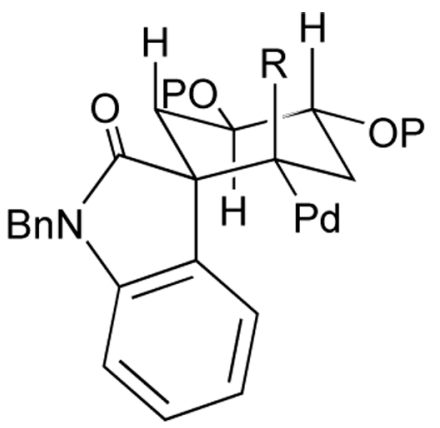

A

$\mathrm{P}=\mathrm{CMe}_{2}$

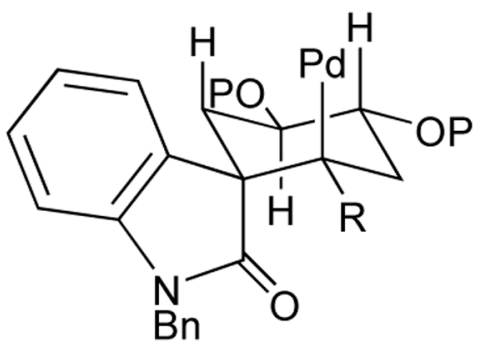

B

\begin{tabular}{|c|c|c|}
\hline substrate & $\mathrm{R}$ & diastereoselectivity A:B \\
\hline $\begin{array}{l}16 a \\
20 a \\
29 a \\
29 c\end{array}$ & $\begin{array}{c}\mathrm{H} \\
\mathrm{CO}_{2} \mathrm{Me} \\
\mathrm{CONBnPh} \\
\mathrm{CONMe}_{2}\end{array}$ & $\begin{array}{c}\text { 80:20 } \\
79: 21 \\
\text { single isomer } \\
\text { single isomer }\end{array}$ \\
\hline
\end{tabular}

FIGURE 2.

Chair conformations of the two possible products resulting from syn insertion and tabulated Heck insertion diastereoselectivity as a function of the $\mathrm{C} 2$ alkenyl substituent; the product resulting from intermediate $\mathbf{A}$ is produced predominantly. 


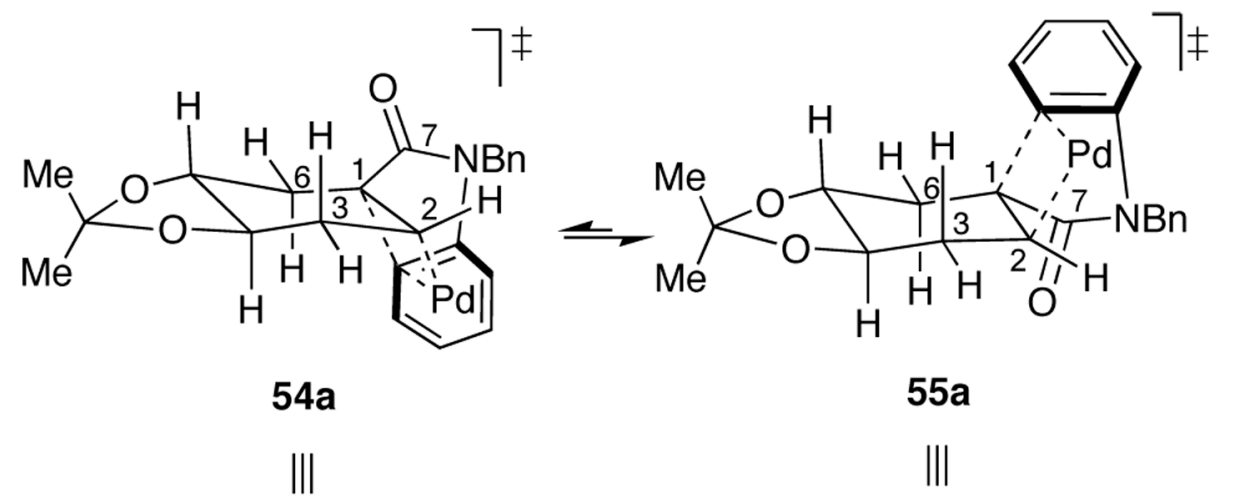

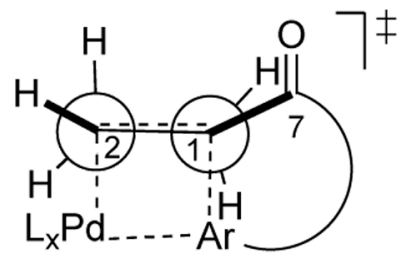

$54 b$

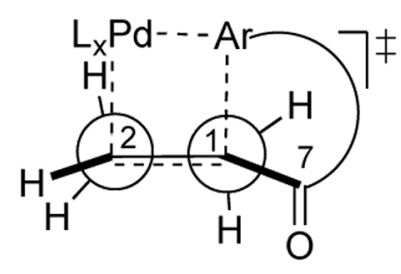

$55 b$

Disfavored

Favored

FIGURE 3.

Representation of the two syn insertion pathways in the acetonide series. Destabilizing eclipsing interactions are avoided in insertion topography $\mathbf{5 5}$. 


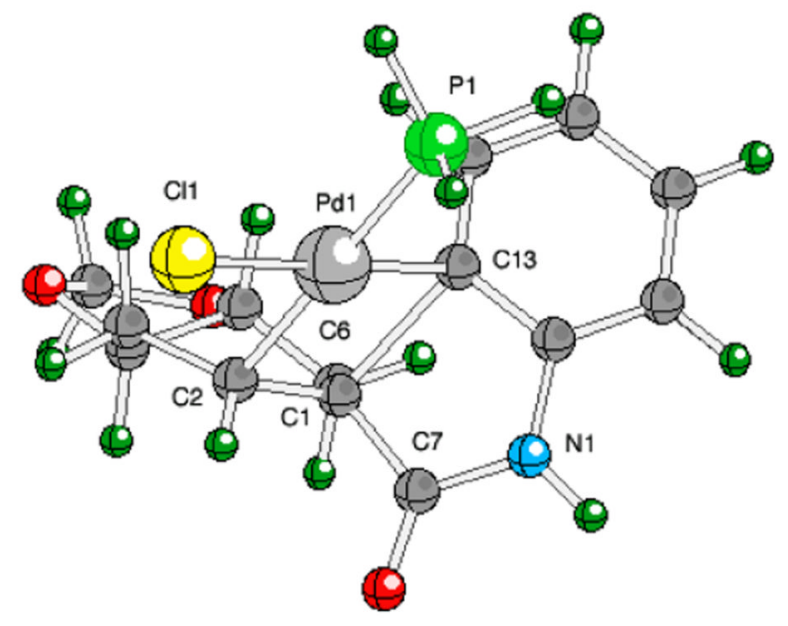

56 (favored) $\Delta \Delta \mathrm{G}^{\ddagger} 373=0.0 \mathrm{kcal} / \mathrm{mol}$

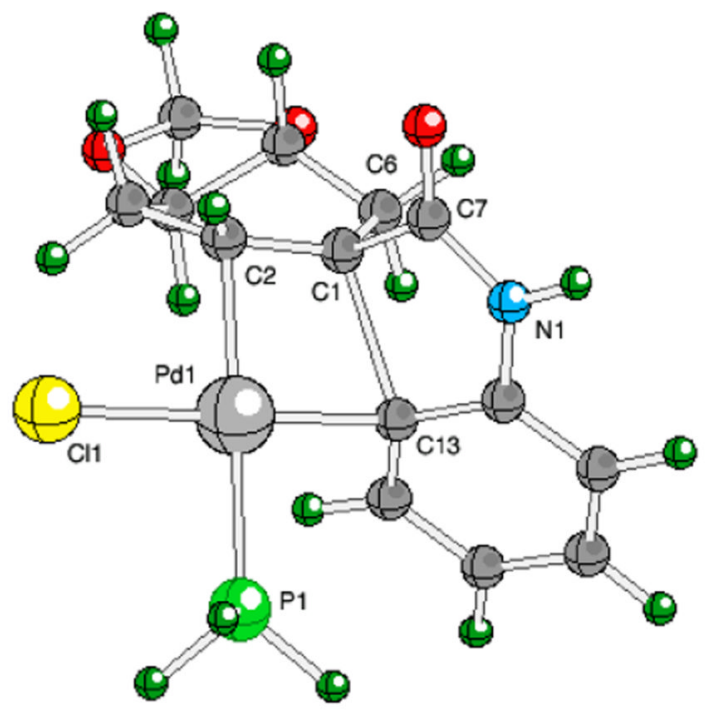

57 (disfavored) $\Delta \Delta \mathrm{G}^{\ddagger}{ }_{373}=1.45 \mathrm{kcal} / \mathrm{mol}$

FIGURE 4.

Calculated (DFT) transition states for competing syn insertion pathways in substrates lacking the $\mathrm{C} 2$ amide. 


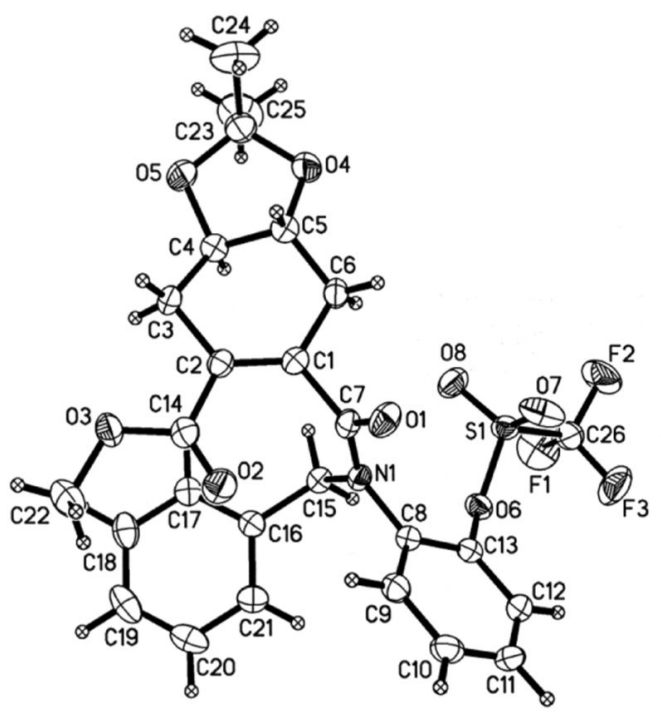

$20 a$

$\angle \mathrm{C} 1-\mathrm{C} 2-\mathrm{C} 14-02=7.8^{\circ}$

$\angle \mathrm{C} 2-\mathrm{C} 1-\mathrm{C} 7-01=99.4^{\circ}$

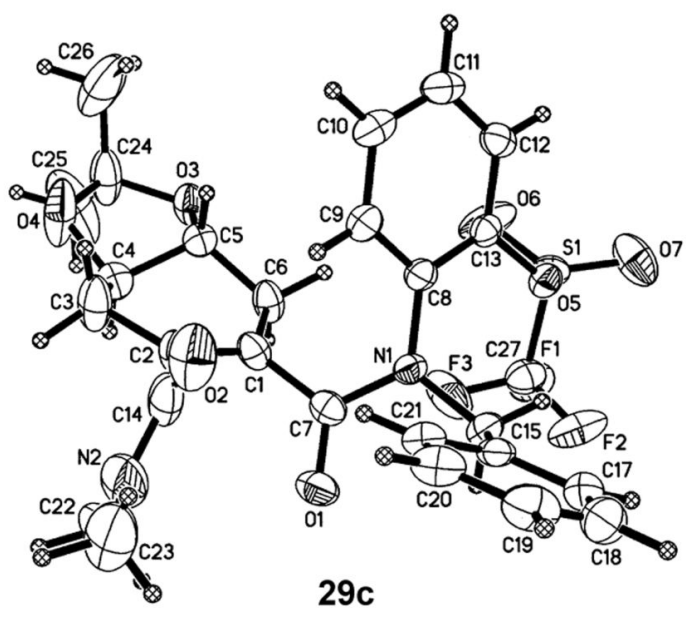

$$
\begin{aligned}
& \angle \mathrm{C} 1-\mathrm{C} 2-\mathrm{C} 14-02=78.7^{\circ} \\
& \angle \mathrm{C} 2-\mathrm{C} 1-\mathrm{C} 7-01=55.7^{\circ}
\end{aligned}
$$

FIGURE 5.

ORTEP representation of the X-ray model of methyl ester 20a and dimethyl amide 29c. 


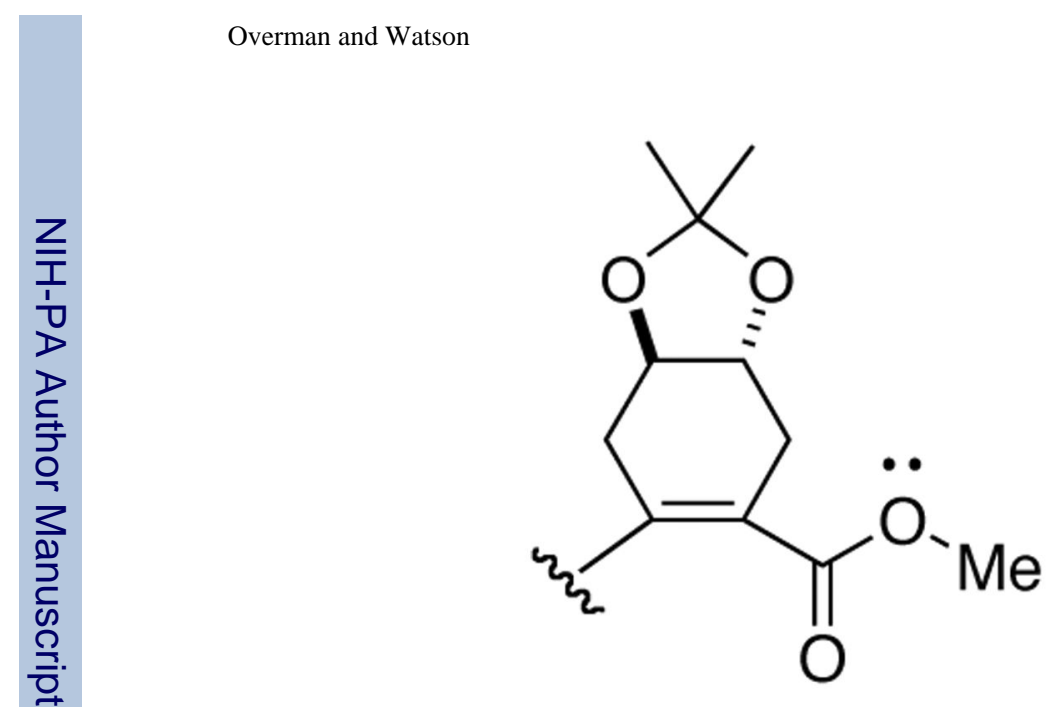

58

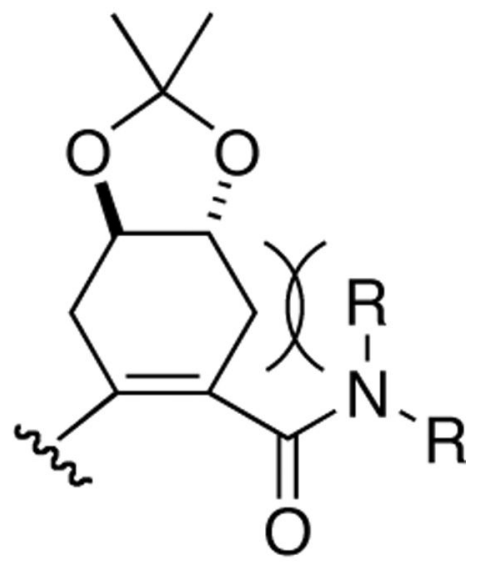

59

FIGURE 6.

Coplanar conformations of cyclization substrates having a methyl ester or tertiary amide substituent at the $\mathrm{C} 2$ vinylic carbon showing the destabilizing steric interactions present in the latter. 


\section{favored modes of migratory insertion}

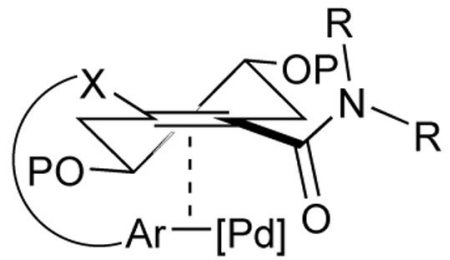

60

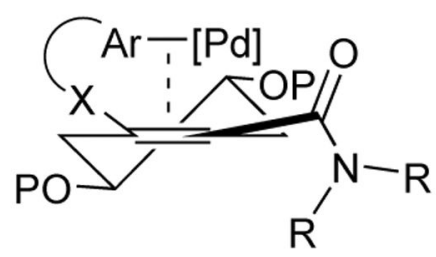

61

\section{disfavored modes of migratory insertion}

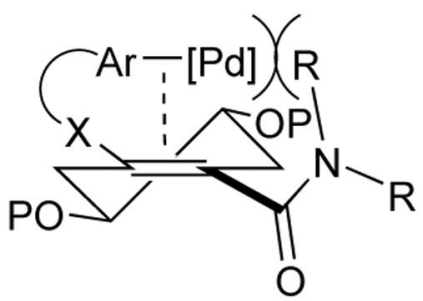

62 or

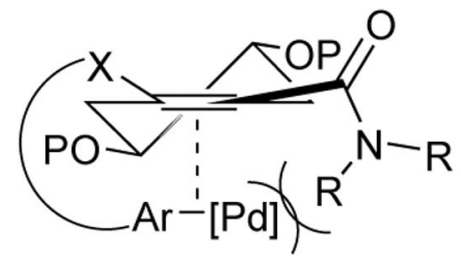

63

FIGURE 7.

Representation of the four syn insertion pathways in the acetonide series for substrates having a perpendicularly oriented amide substituent at $\mathrm{C} 2$. Destabilizing steric interactions between the cis amide substituent and the arylpalladium fragment are avoided in insertion topographies 60 and 61. 


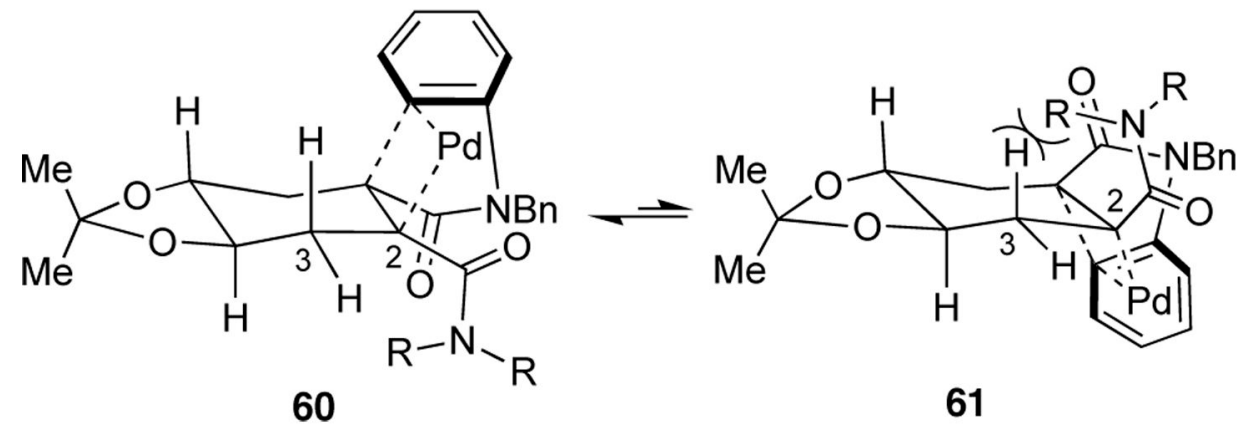

FIGURE 8.

More detailed representation of syn insertion topographies 60 and 61. Syn-pentane-like interactions between the cis amide substituent and $\mathrm{C} 3$ of the cyclohexene are avoided in the favored insertion topography $\mathbf{6 0}$. 


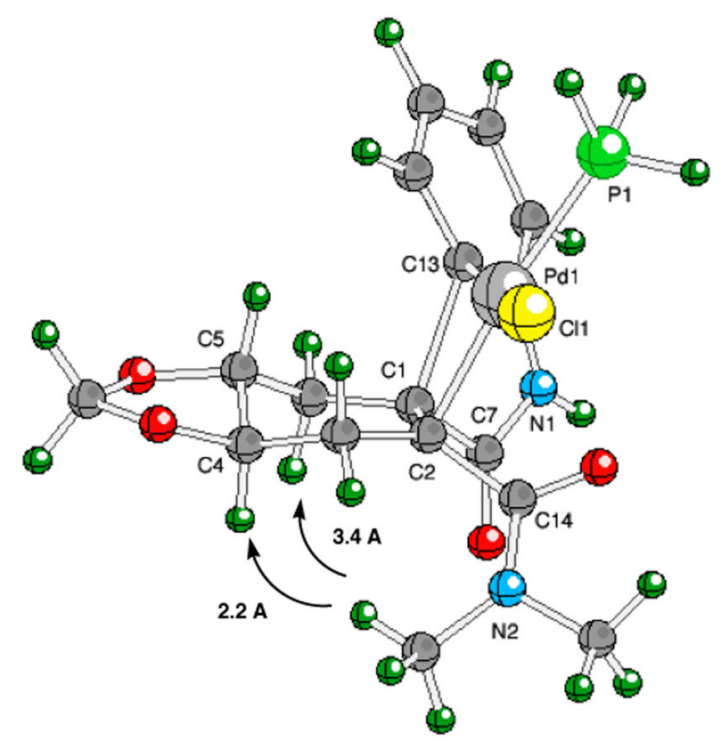

62 (favored) $\Delta \Delta \mathrm{G}^{\ddagger} 373=0.0 \mathrm{kcal} / \mathrm{mol}$

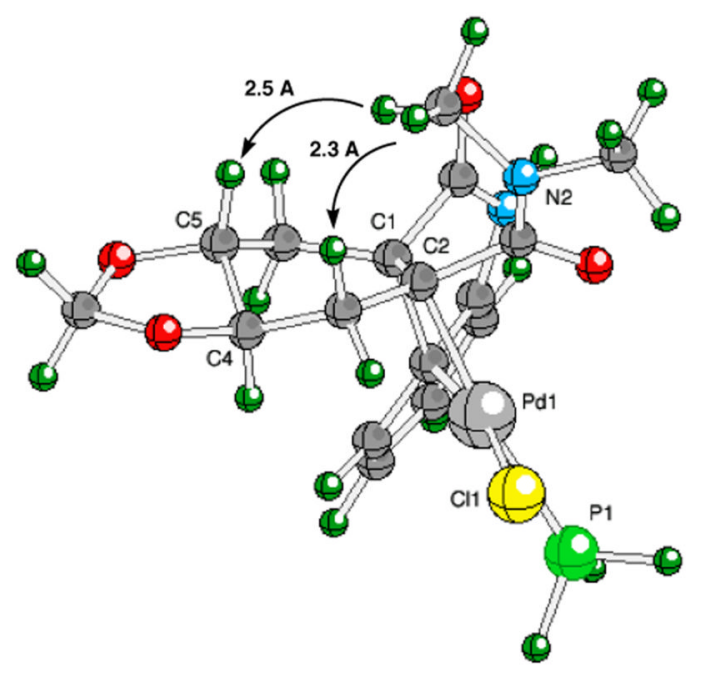

63 (disfavored) $\Delta \Delta \mathrm{G}^{\ddagger} 373=2.16 \mathrm{kcal} / \mathrm{mol}$

FIGURE 9.

Calculated (DFT) transition states for competing syn insertion pathways in substrates containing the $\mathrm{C} 2$ amide. 
<smiles>[X]c1ccccc1NC(=O)C1=C(C(=O)Nc2ccccc2[X])C[C@H]2OC(C)(C)O[C@H]2C1</smiles>
1a: $X=1$

1b: $X=$ OTf

$2,87-90 \%$

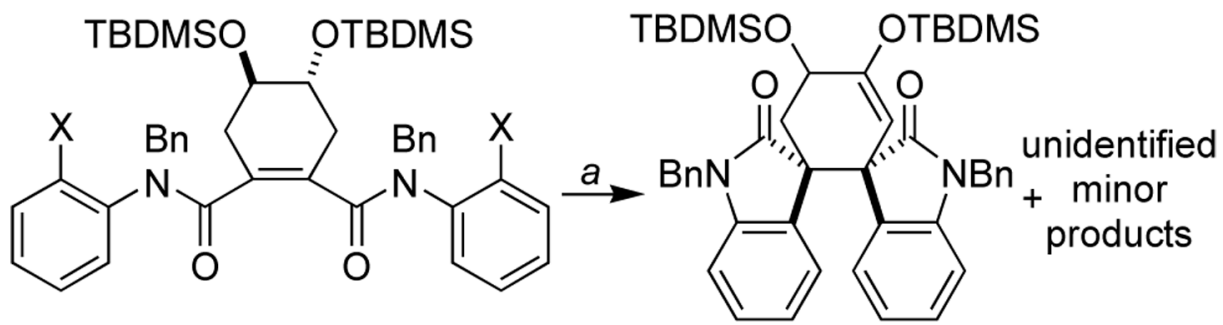

3a: $X=1$

3b: $X=$ OTf

$4,56-64 \%$

SCHEME 1a.

${ }^{a}$ Key: (a) $20 \mathrm{~mol} \% \mathrm{Pd}\left(\mathrm{PPh}_{3}\right)_{2} \mathrm{Cl}_{2}, 10$ equiv $\mathrm{Et}_{3} \mathrm{~N}, \mathrm{~N}, \mathrm{~N}$-dimethylacetamide (DMA), $100{ }^{\circ} \mathrm{C}$, $24 \mathrm{~h}$. 
<smiles>COc1ccccc1NC(=O)C1=C(C(=O)Nc2ccccc2O)CCC(C(=O)Nc2ccccc2O)=C1C(=O)Cl</smiles>

5<smiles>CCOc1ccccc1NC(=O)C1=C(C(=O)Nc2ccccc2OCC)C[C@@H](O)[C@H](O)C1</smiles>

1b: $P=\mathrm{CMe}_{2}, 74 \%$

3b: $P=$ TBDMS, $76 \%$

\section{SCHEME 2a.}

${ }^{a}$ Key: (a) 6, 2,6-lutidine, $\mathrm{Et}_{2} \mathrm{O}$; (b) TBAF; (c) $\mathrm{PhNTf}_{2}, \mathrm{Cs}_{2} \mathrm{CO}_{3}$; (d) $m$-CPBA; (e) cat. TFA, $\mathrm{H}_{2} \mathrm{O}, 80{ }^{\circ} \mathrm{C}$; (f) 2,2-DMP, CSA; (g) TBDMSOTf, 2,6-lutidine. 


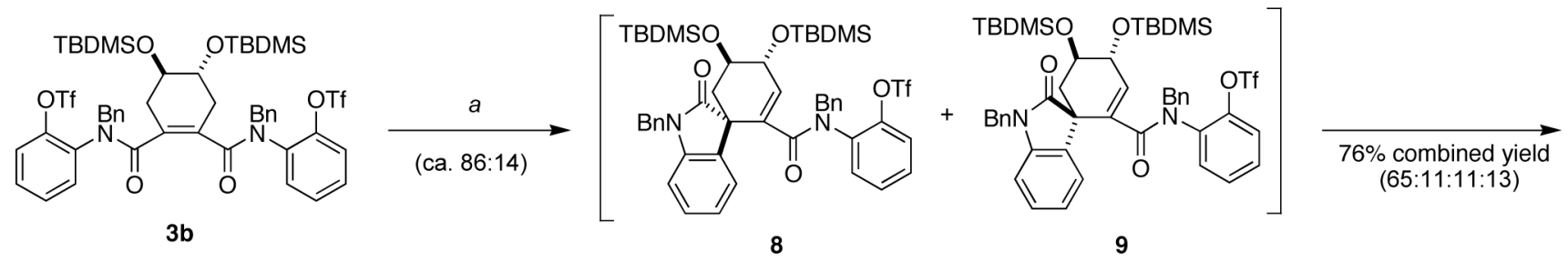

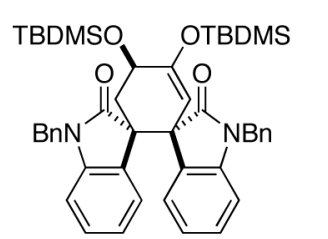

4

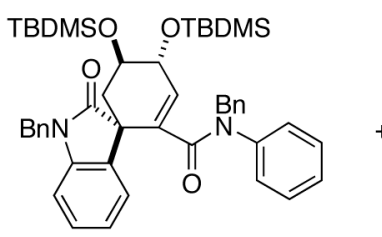

10

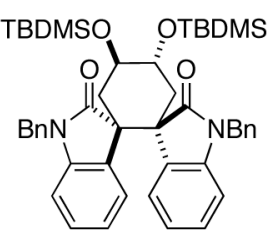

11

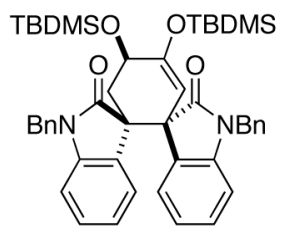

12

SCHEME 3a.

${ }^{a}$ Key: (a) $20 \mathrm{~mol} \% \mathrm{Pd}\left(\mathrm{PPh}_{3}\right)_{2} \mathrm{Cl}_{2}, 10$ equiv $\mathrm{Et}_{3} \mathrm{~N}, \mathrm{DMA}, 100{ }^{\circ} \mathrm{C}, 30 \mathrm{~h}$. 
<smiles>O=C(O)C1=CCC=CC1</smiles>

13<smiles>O=C(Nc1ccccc1O)C1=CCC=CC1</smiles>

14<smiles>COc1ccccc1NC(=O)C1=CC[C@@H](O)[C@H](O)C1</smiles>

15<smiles>O=C(Nc1ccccc1O)C1=CC[C@@H](O)[C@H](O)C1</smiles>

16a: $P=\mathrm{CMe}_{2}, 81 \%$ 16b: $P=$ TBDMS, $86 \%$

SCHEME 4a.

${ }^{a}$ Key: (a) 6, Mukaiyama's salt, 2,4,6-collidine, $\mathrm{PhMe}, 80{ }^{\circ} \mathrm{C}$; (b) $\mathrm{K}_{2} \mathrm{CO}_{3}, \mathrm{H}_{2} \mathrm{O}$; (c) $\mathrm{PhNTf}_{2}$, $\mathrm{Cs}_{2} \mathrm{CO}_{3}$; (d) $m$-CPBA; (e) cat. TFA, $\mathrm{H}_{2} \mathrm{O}, 80^{\circ} \mathrm{C}$; (f) 2,2-DMP, CSA; (g) TBDMSOTf, 2,6lutidine. 
<smiles>COC(=O)C1=C(C(=O)Nc2ccccc2O)CC=CC1</smiles>

17

18<smiles>COC(=O)C1=C(C(=O)Nc2ccccc2O)C[C@@H](O)[C@H](O)C1</smiles>

SCHEME 5a.

${ }^{a}$ Key: (a) $\mathrm{NaOMe} / \mathrm{MeOH},-78{ }^{\circ} \mathrm{C}$; (b) $(\mathrm{COCl})_{2}, \mathrm{CH}_{2} \mathrm{Cl}_{2}$, then 6, 2,6-lutidine, $\mathrm{Et}_{2} \mathrm{O}$; (c) $\mathrm{PhNTf}_{2}$, CsF; (d) $m$-CPBA; (e) cat. TFA, $\mathrm{H}_{2} \mathrm{O}, 80{ }^{\circ} \mathrm{C}$; (f) 2,2-DMP, CSA; (g) TBDMSOTf, 2,6-lutidine. 
<smiles>[R]C(=O)C#CC(=O)Nc1ccccc1OS(C)(C)C(C)C</smiles>

24a: $\mathrm{R}=\mathrm{NBnPh}$

24b: $\mathrm{R}=\mathrm{NMe}_{2}$

26a: $\mathrm{R}=\mathrm{NBnPh}, 32 \%$

26b: $\mathrm{R}=\mathrm{NMe}_{2}, 25 \%$<smiles>[R]C(=O)C1=C(C(=O)Nc2ccccc2O[Tl])CC=CC1</smiles><smiles>[R]C(=O)C1=C(C(=O)Nc2ccccc2O[Te])C[C@@H](O)[C@H](O)C1</smiles>

27a: $\mathrm{R}=\mathrm{NBnPh}, 85 \%$

27b: $\mathrm{R}=\mathrm{NMe}_{2}, 71 \%$

28a: $\mathrm{R}=\mathrm{NBnPh}, 71 \%$

28b: $\mathrm{R}=\mathrm{NMe}_{2}, 78 \%$

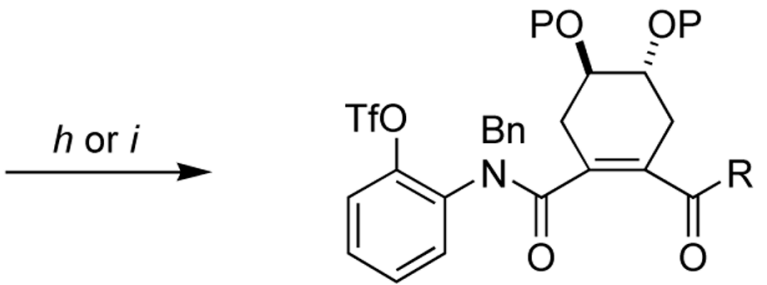

29a: $\mathrm{R}=\mathrm{NBnPh}, \mathrm{P}=\mathrm{CMe}_{2}, 80 \%$

29b: $R=N B n P h, P=$ TBDMS, 94\%

29c: $R=\mathrm{NMe}_{2}, \mathrm{P}=\mathrm{CMe}_{2}, 86 \%$

\section{SCHEME 6a.}

${ }^{a}$ Key: (a) $n$-BuLi or LiHMDS, then $\mathrm{CO}_{2},-78{ }^{\circ} \mathrm{C}$; (b) EDCI, 25; (c) 1,3-butadiene, $\mathrm{EtAlCl}_{2}$, 2,6-di-tert-butyl-4-methylpyridine (DTBMP), PhMe, rt, 48 h; (d) PhNTf 2 , CsF; (e) m-CPBA; (f) cat. TFA, $\mathrm{H}_{2} \mathrm{O}, 80{ }^{\circ} \mathrm{C}$; (h) 2,2-DMP, CSA; (i) TBDMSOTf, 2,6-lutidine. 


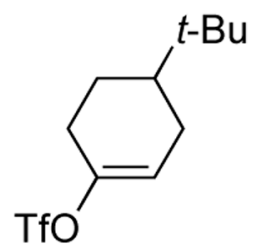

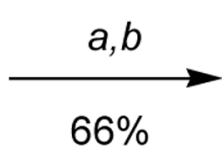

30<smiles>CC(C)(C)[14C]1CC=C(C(=O)Nc2ccccc2OCc2ccccc2)CC1</smiles>

31

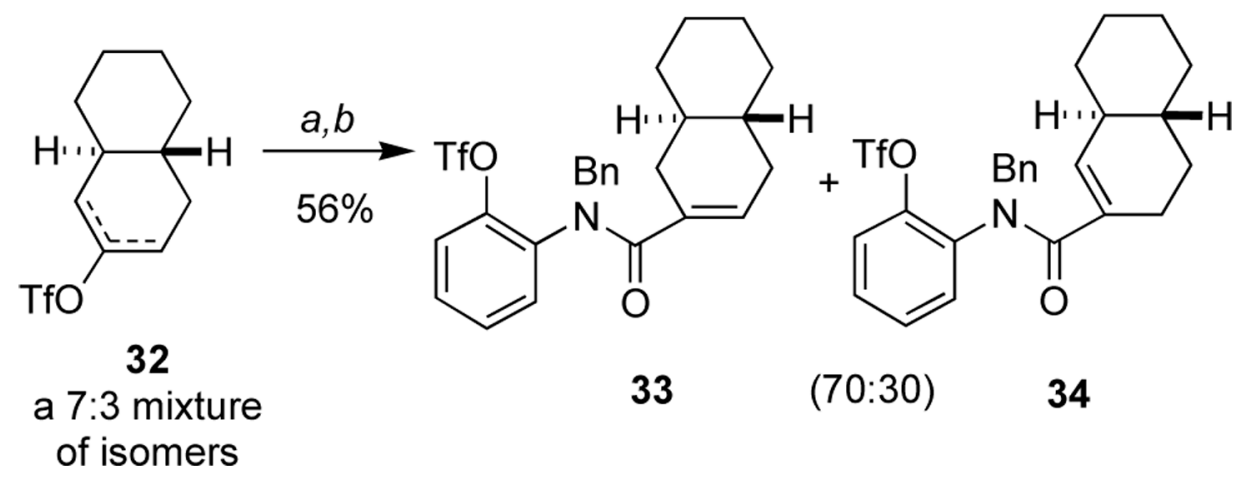

SCHEME 7a.

${ }^{a}$ Key: (a) 5-10 mol\% $\mathrm{Pd}\left(\mathrm{PPh}_{3}\right)_{2} \mathrm{Cl}_{2}, 25, \mathrm{CO}(1 \mathrm{~atm}), \mathrm{Bu}_{3} \mathrm{~N}, 100{ }^{\circ} \mathrm{C}$; (b) $\mathrm{PhNTf}_{2}, \mathrm{CsF}$, $\mathrm{Cs}_{2} \mathrm{CO}_{3}$. 


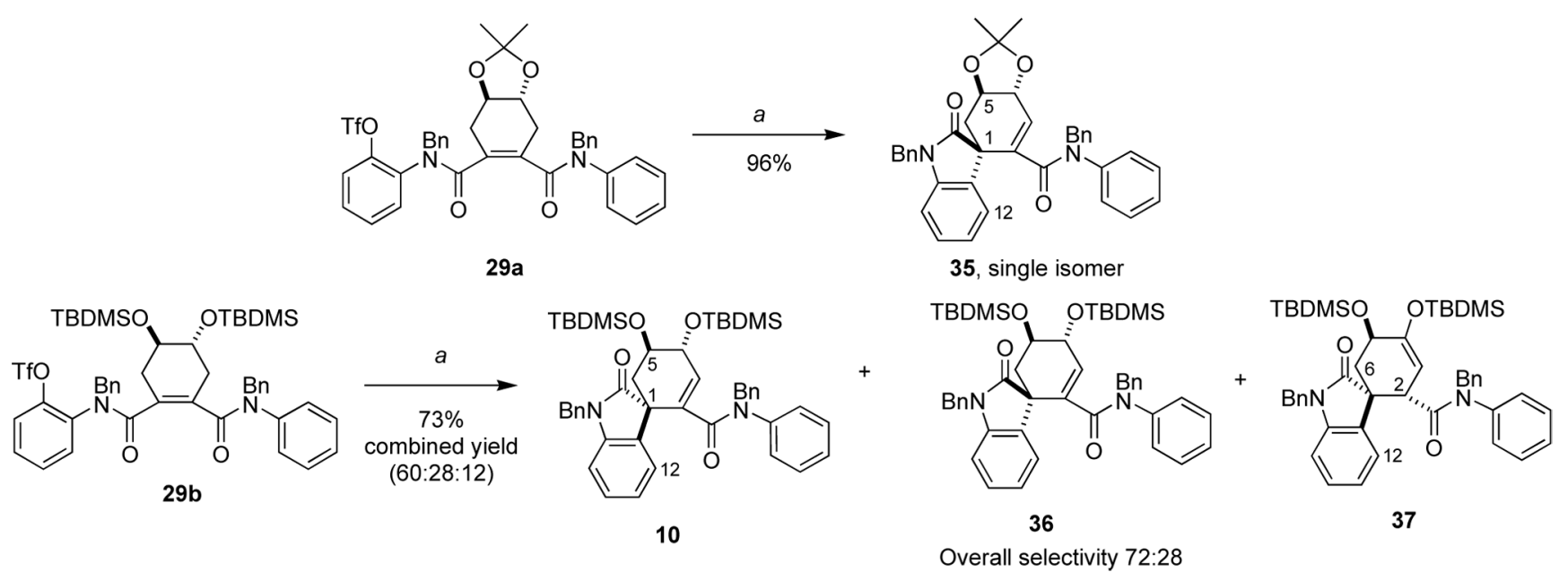

SCHEME 8a.

${ }^{a}$ Key: (a) $20 \mathrm{~mol} \% \mathrm{Pd}\left(\mathrm{PPh}_{3}\right)_{2} \mathrm{Cl}_{2}, 10$ equiv Et $3 \mathrm{~N}, \mathrm{DMA}, 100{ }^{\circ} \mathrm{C}, 24 \mathrm{~h}$. 
<smiles>CC1(C)O[C@H]2CC=C(C(=O)Nc3ccccc3O[Na])C[C@H]2O1</smiles>

$16 a$<smiles>CC1(C)OC2CC3(C=C[C@@H]2O1)C(=O)N(Cc1ccccc1)c1ccccc13</smiles>

$38 \quad(80: 20)$

39

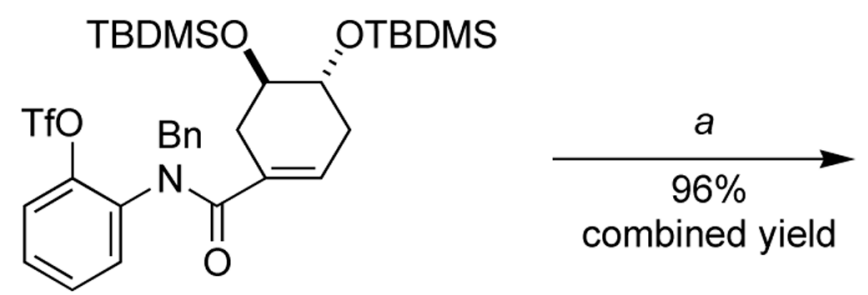

$16 b$

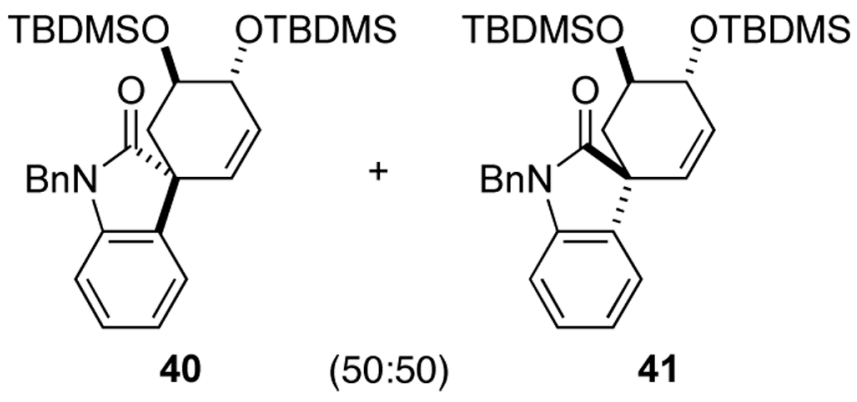

SCHEME 9a.

${ }^{a}$ Key: (a) $20 \mathrm{~mol} \% \mathrm{Pd}\left(\mathrm{PPh}_{3}\right)_{2} \mathrm{Cl}_{2}, 10$ equiv Et $3 \mathrm{~N}$, DMA, $100{ }^{\circ} \mathrm{C}, 24 \mathrm{~h}$. 

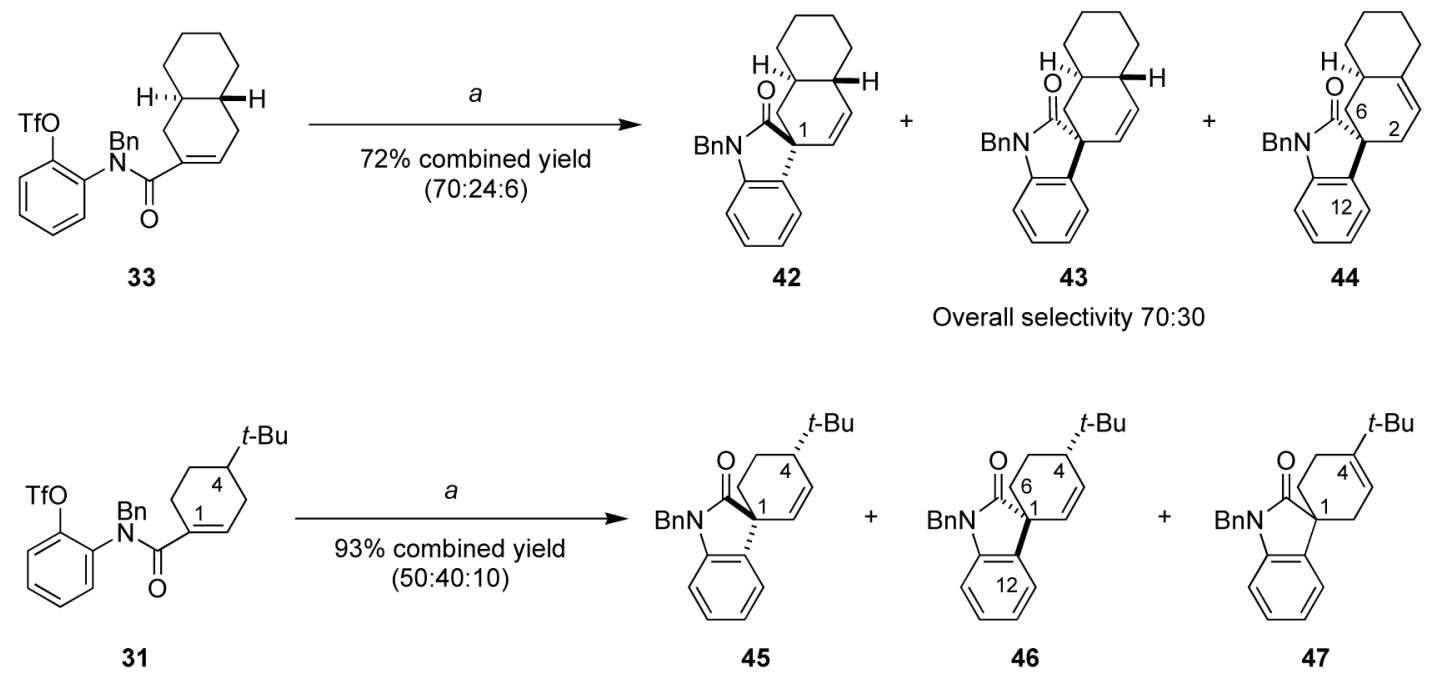

SCHEME 10a.

${ }^{a}$ Key: (a) $20 \mathrm{~mol} \% \mathrm{Pd}\left(\mathrm{PPh}_{3}\right)_{2} \mathrm{Cl}_{2}, 10$ equiv $\mathrm{Et}_{3} \mathrm{~N}$, DMA, $100{ }^{\circ} \mathrm{C}, 24 \mathrm{~h}$. 
<smiles>COC(=O)C1=C(C(=O)Nc2ccccc2O)C[C@H]2OC(C)(C)O[C@@H]2C1</smiles><smiles>COC(=O)C1=C[C@@H]2OC(C)(C)O[C@@H]2C=C1C(=O)OC</smiles>

48

49

50

Overall selectivity $79: 21$<smiles>COC(=O)C1=C(C(=O)Nc2ccccc2O)C[C@@H](O[GaH2])[C@H](OS(C)(=O)=O)C1</smiles>

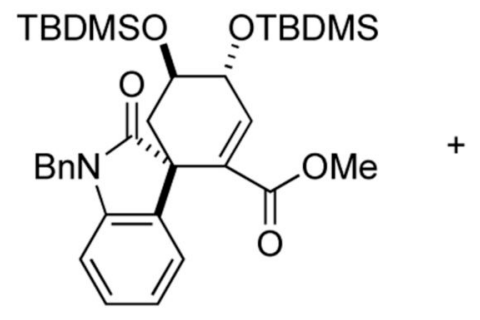

51

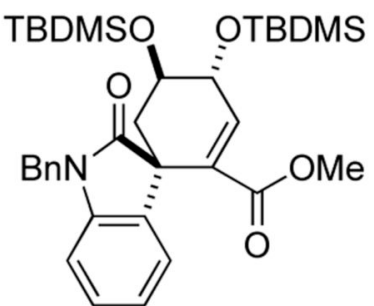

52

SCHEME 11a.

${ }^{a}$ Key: (a) 20 mol\% $\mathrm{Pd}\left(\mathrm{PPh}_{3}\right)_{2} \mathrm{Cl}_{2}, 10$ equiv $\mathrm{Et}_{3} \mathrm{~N}, \mathrm{DMA}, 100{ }^{\circ} \mathrm{C}, 24 \mathrm{~h}$. 